NBER WORKING PAPER SERIES

\title{
PHYSICAL AND HUMAN CAPITAL DEEPENING AND NEW TRADE PATTERNS IN JAPAN
}

\author{
Keiko Ito \\ Kyoji Fukao \\ Working Paper 10209 \\ http://www.nber.org/papers/w10209
NATIONAL BUREAU OF ECONOMIC RESEARCH 1050 Massachusetts Avenue Cambridge, MA 02138
January 2004

The authors would like to thank the editors of this volume and the discussants, Chin Hee Hahn and Ji Chou, and participants of the Fourteenth NBER Annual East Asian Seminar on Economics for their helpful comments. The authors are also grateful to Yoshimasa Yoshiike and Tangjun Yuan for undertaking meticulous data calculations.

The views expressed herein are those of the authors and not necessarily those of the National Bureau of Economic Research.

(C2003 by Keiko Ito and Kyoji Fukao. All rights reserved. Short sections of text, not to exceed two paragraphs, may be quoted without explicit permission provided that full credit, including $(\subset$ notice, is given to the source. 
Physical and Human Capital Depening and New Trade Patterns in Japan

Keiko Ito and Kyoji Fukao

NBER Working Paper No. 10209

January 2004

JEL No. C23, F14, F16

\section{ABSTRACT}

This paper investigates the deepening of the international division of labor and its effect on factor intensities in Japan, mainly focusing on the manufacturing sector. In the first half of the paper, we analyze the factor contents of trade and find that Japan's factor content net-exports of capital and non-production labor grew rapidly while net-exports of production workers fell by a large amount during the period from 1980-2000. Interestingly, the decline in the factor content of net-exports of production workers was almost entirely caused by Japan's trade with China and Hong Kong. According to our decomposition analysis, however, most of the macro-economic change in the capital-labor ratio and the change in the skilled-labor ratio is attributable to a "within-industry"shift rather than a "between-industry" shift. Although we clearly see a drastic increase in VIIT and outsourcing to foreign countries, particularly to Asian countries, our empirical analysis provides only weak evidence that the deepening international division of labor contributes to changes in factor intensities in each industry. Our results suggest that specialization in the export of skilledlabor-intensive products may have contributed to the increase in the relative demand for skilled (professional, technical, managerial, and administrative) labor within industry. However, our results suggest that changes in trade patterns (specialization in capital-intensive production) cannot explain the rapid growth of capital-labor ratios in Japan.

Keiko Ito

The International Centre for the Study of East Asian Development

11-4 Otemachi, Kokurakita

Kitakyushu, Fukuoka 803-0814

Japan

ito@icsead.or.jp

Kyoji Fukao
Institute of Economic Research

Hitotsubashi University

2-1 Naka, Kunitachi

Tokyo 186-8603

Japan

k.fukao@srv.cc.hit-u.ac.jp 


\section{Introduction}

Until the beginning of the 1990s, Japan accomplished comparatively high economic growth through an exceptionally rapid accumulation of physical and human capital. Table 1.1 compares growth accounting results for the US economy (by Jorgenson, Ho, and Stiroh, 2002) with those for the Japanese economy (Fukao, Inui, Kawai, and Miyagawa, 2003). We can see that, compared with the US, Japan's economic growth until 1990 was relatively more dependent on labor quality growth and increases in physical capital per capita. However, as is well-known, high economic growth based on rapid capital accumulation is not sustainable in the long-run because of the diminishing rate of return to physical and human capital.

\section{INSERT Table 1.1}

Evidence suggests that Japan is caught in this trap of diminishing rates of return. Figure 1.1 shows that as the physical capital-output ratio increased over the past three decades in Japan, the rate of return to physical capital declined continuously. Comparing South Korea and Japan with other OECD economies, Pyo and Nam (1999), showed that the two countries both enjoyed a more rapid rise in their capital output ratios but also suffered a faster decline in the rate of return to capital. Turning from physical to human capital, Katz and Revenga (1989) found that while educational earnings differentials expanded drastically in the US in the 1980s, the college wage premium in Japan increased only slightly. As Genda (1997) showed, the underlying reason is that the employment of skilled workers such as older college graduate males expanded rapidly in Japan, resulting in an excess supply of skilled workers relative to the limited availability of management positions that contributed to the stagnation of earnings for older college graduates. Probably partly as

a result of these declines in the rate of return, the accumulation of physical and human capital has 
slowed down over the past decade (Table 1.1). ${ }^{1}$

\section{INSERT Figure 1.1}

We should note that according to standard international trade theory, rapid growth based on capital accumulation will be sustainable if the economy gradually specializes in physical and human capital intensive products. Under such a specialization process, the factor price equalization mechanism will work to offset the diminish rate of return to physical and human capital. For Japan, the 1990s were an age of "globalization": the country has expanded its international division of labor with other East Asian countries through international trade and direct investment. The purpose of this paper is to examine this deepening of the international division of labor and evaluate how much of the diminishing rate of return mechanism was cancelled out by the international division of labor.

Several recent studies, such as Feenstra and Hanson (1996b, 1999, 2001), Kimura (2001), and Fukao, Ishido, and Ito (2003), have shown that the fragmentation of the production process and vertical intra-industry trade between developed and developing economies may have enhanced the vertical division of labor within each industry. This type of international division of labor would cause a deepening of the physical and human capital within each industry in developed economies. However, since the resulting capital deepening will occur within each industry, we cannot correctly analyze this type of division of labor by using inter-industry trade data. Consequently, we study the international division of labor by looking at both inter-industry trade and intra-industry trade.

The remainder of the paper is organized as follows. In section 2, we examine physical and human capital deepening in Japan. In section 3, we take a broad look at Japan's inter-industry trade and factor contents in order to measure to what extent Japan's capital deepening is offset by

\footnotetext{
${ }^{1}$ Godo (2001) found that the speed of catch-up of Japan's average schooling years to the US level slowed down during the 1980s because of the decline in the Japan/US ratio in average schooling years for tertiary education.
} 
international trade. In section 4, after providing an overview of the changes in Japan's intra-industry trade and vertical division of labor, we conduct econometric analyses to investigate the determinants of the changes in factor intensities using industry-level data. Section 5, finally, presents our conclusions.

\section{Physical and Human Capital Deepening in the Japanese Economy}

In this section, we look at the trends of physical and human capital deepening in Japan and examine the macro-economic change in the capital-labor ratio and the change in the skilled-labor ratio (the percentage of skilled labor in total labor) by decomposing these changes into the contribution of the increase in the capital-labor ratio or the share of non-production workers within each industry (the "within effect") and the contribution of the reallocation between industries (the "between effect").

First, we consider the increase in the capital-labor ratio and the share of non-production (or skilled) workers in the manufacturing sector as well as the Japanese economy as a whole. As Figure 2.1 shows, the capital-labor ratio measured as real capital stock (in 1990 price) divided by the number of workers has increased considerably over the last three decades: the capital-labor ratio for both the economy as a whole and manufacturing industry grew five-fold from three million yen per person in 1970 to 15 million yen per person in 1998.

\section{INSERT Figure 2.1}

In order to examine the human-capital deepening in Japan, we compiled data on the number of non-production or skilled workers using the data of the Population Census. "Skilled workers" are persons whose profession is classified either as "professional and technical" or as "managerial and administrative." We define "non-production workers" here as persons whose profession falls into one of the following categories: professional and technical occupations, managers and administrators, 
clerical and secretarial occupations, sales occupations, services occupations, protective occupations, occupations in agriculture, forestry and fishing, occupations in transportation and telecommunications, and other occupations. The definition of "non-production workers" is much broader than the definition of "skilled workers" and includes not-highly educated workers. The share of non-production (or skilled) workers in the total number of workers has been increasing, as shown in Figure 2.2, though the growth rate is much more moderate than that of the capital-labor ratio. In the period from 1980-2000, the share of non-production workers in manufacturing increased from $27.7 \%$ in 1980 to $30.7 \%$ in $2000 .^{2}$ The share of skilled workers also grew during $1980-2000$ : in the manufacturing sector, it rose from $9.0 \%$ to $10.5 \%$, while in the economy as a whole it expanded from $9.8 \%$ to $13.9 \% .^{3}$

\section{INSERT Figure 2.2}

The increase in the capital-labor ratio and in the share of non-production (or skilled) workers can be decomposed into the contribution of the increase within each industry ("within effect") and the contribution of the reallocation between industries ("between effect") using the following decomposition formula:

$$
\begin{aligned}
\Delta P= & \sum_{i=1}^{n} \bar{S}_{i} \Delta P_{i}+\sum_{i=1}^{n} \bar{P}_{i} \Delta S_{i} \\
& i \text { industry }(i=1,2, \quad \ldots, \mathrm{n}) \\
P & =\sum_{i=1}^{n} K_{i} / \sum_{i=1}^{n} L_{i}, \text { or } \sum_{i=1}^{n} L_{s, i} / \sum_{i=1}^{n} L_{i} \\
P_{i} & =K_{i} / L_{i}: \text { Capital-labor ratio in industry } i, \text { or }
\end{aligned}
$$

\footnotetext{
2 This latter value, though, is substantially below the peak of $32.3 \%$ reached in 1997 . The decline in the share of non-production workers since 1998 is most likely the result of firms' restructuring efforts - the dismissal of managers, sales personnel, etc. - following the further deterioration of the Japanese economy.

${ }^{3}$ For details on the compilation of the skilled/non-production workers data, see Appendix.
} 
$=L_{s i} / L_{i}:$ Share of non-production (or skilled) workers in total number of workers in industry $i$

$S_{i}=L_{i} / L$ : Share of workers in industry $i$ in total number of workers in the economy as a whole or in the manufacturing sector

Variables with an upper bar denote the average value of the period. $\Delta$ denotes the change in the variable overtime. The first term of the right hand side represents the increase in the factor intensity within each industry ("within effect") while the second term represents the reallocation between industries ("between effect").

Ideally, we should use the most disaggregated cross-industry data available for our decomposition analysis. However, because of the data limitation, we had to use the relatively aggregated data of the JIP database for our decomposition analysis. ${ }^{4}$ We should note that our estimates of the within effect might suffer from upward biases as a consequence of this aggregation problem.

The results of our decomposition analysis are reported in Tables 2.1 and 2.2. Table 2.1, which summarizes the decomposition of capital-labor ratio growth, shows that there was a negative between effect for most periods of 1970-1998, indicating the decline of the capital-intensive sectors of the economy. Moreover, the magnitude of the between effect is very small throughout the entire 1970-1998 period and most part of the growth of capital-labor ratio is attributable to the within effect. On the other hand, Table 2.2, which summarizes the decomposition of the growth of the share of skilled or non-production workers, shows that here the between effect was positive in all cases, showing that the share of human capital intensive industries has continuously increased both in the manufacturing sector and in the economy as a whole. The within effect was also positive with the

\footnotetext{
${ }^{4}$ In the following decomposition, we used data of 35 manufacturing industries and 43 non-manufacturing industries.
} 
exception of two cases in the period of 1990-2000, and it was always greater than the between effect except for these two cases. The major implication of our results is that the within effect is very large. Some part of the within effect may have been caused by the international division of labor within each industry. We analyze this issue in section 4.

INSERT Tables 2.1 and 2.2

Our decomposition analysis thus suggests that physical and human capital deepening in the Japanese economy is mostly attributable to the within-industry shift, not to the between-industry shift, though we could see a negative between effect during the period 1990-2000 for the share of non-production workers in the manufacturing sector and the share of skilled workers in the whole economy. In the last two decades, and particularly in the 1990s, the age of "globalization," both the within-industry capital deepening and the between-industry allocation may have been caused by expanding international trade. The between-industry shift may be partly explained by the change in patterns of inter-industry trade which affects the size of each industry in Japan, while the within-industry shift may be explained by the change in patterns of intra-industry trade which affects the mixes of factor inputs in each industry. In the following sections, we will examine the change in Japan's trade patterns and analyze the determinants of the changes in factor intensities in Japan.

\section{Japan's Inter-industry Trade and Factor Contents}

In this section, we take a general look at the pattern of Japan's inter-industry trade in the last two decades. Next, we estimate how factor contents in Japan's international trade changed during this period.

\subsection{Overview of Japan's International Trade}

Although Japan's overall import-GDP ratio has gradually declined over the last two decades, 
imports of manufactured products have actually grown faster than the economy as a whole (Table 3.1). As Figure 3.1.B shows, the increase in imports mainly concentrated on electrical machinery and labor intensive goods, such as apparel and wooden products, which in this figure are classified as "other manufacturing products." Since the share of the manufacturing sector in GDP declined during this period, the ratio of imports of manufactured products to gross value added in the manufacturing sector increased rapidly: by 11.5 percentage-points from $15.2 \%$ in 1985 to $26.7 \%$ in 2000 (Table 3.1 ). The United States experienced a similar trend during the 1980s, when this ratio jumped by 12.4 percentage-points from $18.3 \%$ in 1978 to $30.7 \%$ in 1990 (Sachs and Shatz 1994). We would expect an impact of a similar scale on Japan's manufacturing sector as a result of the recent surge in imports.. ${ }^{5}$

\section{INSERT Table 3.1 and Figure 3.1}

On the other hand, the commodity composition of Japan's exports at the two-digit level has remained relatively stable over the last fifteen years (Figure 3.1.A). Nevertheless, looking at trade patterns at a more detailed commodity classification level, it becomes clear that Japan's specialization has changed: the country is increasingly specializing in the export of capital goods and key parts and components in the automobile and electrical machinery sector, while it has become a net importer of many household electrical goods. ${ }^{6}$

Japan's new imports of electrical machinery and labor intensive products are mainly provided by East Asian economies. Figure 3.2 shows that nine East Asian economies (China, Hong Kong,

\footnotetext{
${ }^{5}$ Comparing export shares and import penetration in the US, Canada, UK and Japan during the period from 1974-93, Campa and Goldberg (1997) found import penetration to be extremely stable and significantly lower in Japan than in the other countries. However, if we were to conduct a similar analysis using more recent data, it seems probable that this conclusion no longer holds.

${ }^{6}$ The share of machine parts in Japan's total exports to East Asia increased from $31.7 \%$ in 1990 to $40.2 \%$ in 1998, while the share of capital goods, which include some machine parts, increased from $53.2 \%$ to $56.8 \%$ during the same period (MITI 1999).
} 
Taiwan, Korea, Singapore, Indonesia, Thailand, the Philippines, and Malaysia) provided $64.2 \%$ of Japan's electrical machinery imports and $49.2 \%$ of Japan's imports of “other manufacturing products" in 2000. The East Asian economies' share in Japan's total imports of machinery and intermediate products such as metal products and chemical products has also increased rapidly.

\section{INSERT Figure 3.2}

As a result of these trends, East Asia during the 1990s became the most important destination for and origin of Japan's international trade. As Figure 3.3 shows, trade with the nine East Asian economies accounted for $48.5 \%$ of Japan's total manufactured imports and $41.0 \%$ of total manufactured exports in 2000 .

\section{INSERT Figure 3.3}

This rise in Japan's imports of labor intensive products and exports of capital and technology intensive products (such as machinery and advanced intermediate products) can be easily recognized as a deepening of the international division of labor with the relatively unskilled-labor abundant East Asian economies. But how can we interpret the rapid increase in the two-way trade in electrical machinery? Table 3.2, presenting Japan's bilateral trade in electrical machinery with China and Hong Kong in 1999 at the 3-digit level, provides a clue.

\section{INSERT Table 3.2}

This table shows two important facts. First, at the detailed commodity level, there seems to be a division of labor within the electrical machinery industry. With China and Hong Kong, Japan is a net importer of relatively labor-intensive products (such as television and radio-broadcast receivers and electrical household goods) and a net exporter of technology-intensive other products. This means that in order to correctly understand the division of labor and factor contents in trade between Japan and East Asia, we need to analyze trade patterns at the detailed commodity level; otherwise, the analysis will suffer from aggregation bias problems (Feenstra and Hanson 2000). 
The second important fact this table shows is the existence of huge intra-industry trade between Japan and China plus Hong Kong. For example, in the case of television receivers, the total trade value is 37 times greater than the trade balance. It seems that we need to analyze intra-industry trade in order to correctly evaluate the impact of trade on Japanese economy.

\subsection{Factor Contents in Japan's Trade of Manufacturing Products}

In this subsection, we analyze the changes in factor contents in Japan's trade. In order to avoid aggregation bias, we should calculate factor contents at the most disaggregated level possible. ${ }^{7}$ The most disaggregated data on direct factor requirements are those available in the Report on Industrial Statistics of the Ministry of International Trade and Industry, which is based on the Census of Manufactures. The data is classified by the 4-digit Standard Industrial Classification for Japan, which listed 540 manufacturing industries in 1990.

There is no direct converter between this industry classification and the 9-digit HS classification used by the Ministry of Finance for the compilation of Japan's international trade statistics. In order to link the two sets of data - factor requirements and international trade - we used the basic industry classification of the Japan Input-Output Tables 1990 by the Management and Coordination Agency, which lists 341 manufacturing industries, as our benchmark classification. Using supplementary converter tables of the I-O statistics, we converted both the factor requirement data and the international trade data into the basic I-O classification. As a result, we obtain factor requirement and international trade data for 246 manufacturing industries. ${ }^{8}$ In order to estimate

\footnotetext{
7 Using Management and Coordination Agency, Japanese Government "1980-85-90 Linked Input-Output Tables," Sakurai (2001) estimated factor contents in Japan's trade for the years 1980, 85, and 90.

8 The factor requirement data of the Census of Manufactures is on an establishment basis and each establishment is classified by its most important product. Since many establishments produce various commodities simultaneously, this classification method is problematic. The I-O converter from the
} 
indirect factor requirements, we used the corresponding I-O table.

Ideally, we would use up-to-date factor requirement data and I-O tables in order to take account of technology change in Japan. Unfortunately, the factor requirement data is available only until 1990, because the Census of Manufactures after that year does not cover headquarter activities. Because of this constraint, we used constant factor requirement and I-O data of 1990 for our analysis of the entire 1980-2000 period. $^{9}$

Factor content in Japan's trade in year $t(t=1980,1990,2000)$ is calculated by

$$
\boldsymbol{X}_{t}=\boldsymbol{D}(\boldsymbol{I}-\boldsymbol{A})^{-1} \boldsymbol{T}_{t}
$$

where $(K \times 1)$ vector $\boldsymbol{X}_{\boldsymbol{t}}=\left[x_{k, t}\right]$ denotes the total contents of factor $k$ in Japan's trade of year $t .(K \times J)$ matrix $\boldsymbol{D}=\left[d_{k, j}\right]$ denotes the quantity of primary factor $k$ directly used per unit of output in industry $j$ in year 1990. $(J \times J)$ matrix $\boldsymbol{A}$ is the input-output matrix of year $1990{ }^{10}(J \times 1)$ vector $\boldsymbol{T}_{t}$ is the net-export vector of year $t$ in 1990 prices. In order to derive trade data in 1990 prices, we used the deflators of the Management and Coordination Agency's Japan Linked Input-Output Table (various years) and the Wholesale Price Index of the Bank of Japan at the 3-digit level. ${ }^{11}$

We analyzed factor content in terms of the following four primary factors: physical capital (in

Census of Manufactures to the basic I-O classification takes account of this problem and converts establishment-based data into activity-based data. We used the I-O converter in order to construct the factor requirement data for each I-O classification-based industry. Therefore, our factor requirement data were also transformed into the activity-based data.

${ }^{9}$ Because of this methodology, there is a risk of overestimating factor contents in recent trade in the case of industries where total factor productivity has grown rapidly.

${ }^{10}$ The input-output matrix here covers only manufacturing industries. Therefore, our analysis does not include indirect factor requirements through changes in production in non-manufacturing industries.

${ }^{11}$ The conversion of trade statistics at the HS 9-digit level into trade data at classified at the basic industry level of the I-O tables in 1990 price was conducted by H. Nosaka, T. Inui, K. Ito and K. Fukao as part of the Japan Industrial Productivity (JIP) database project. The result is included in the JIP database. For more detail on this database see Fukao, Inui, Kawai, and Miyagawa (2003). 
1990 prices, book value), production labor (number of workers), non-production labor (number of workers), and land (in 1990 prices, book value). In order to analyze how the increase in Japan's trade with the East Asian economies affected Japan's factor markets, we subdivided Japan's total net exports in each industry into gross exports and gross imports by six regions, namely, (1) China and Hong Kong, (2) the NIEs-3 (Taiwan, South Korea, and Singapore), (3) the ASEAN-4 (Indonesia, Thailand, Malaysia, and The Philippines), (4) the US, (5) the EU, and (6) all other economies.

The results of the factor content analysis for the years 1980, 1990, and 2000 are reported in Table 3.3. Reflecting Japan's huge trade surplus, Japan is a net exporter of all the four primary factors. For example, according to our calculations, in the year 2000, Japan recorded factor-content net exports of 363,000 production workers, which represents $4.7 \%$ of the total of production workers $(7,717,000)$ in manufacturing in 1990 . Compared with the trade pattern observed in 1990 , the 2000 figure for factor content net-exports of production labor represents a decline of $42 \%$. This decline was almost entirely caused by Japan's trade with China and Hong Kong (Table 3.4). In the year 2000, about one-third of factor content gross-imports of production workers came from China and Hong Kong (Table 3.3).

\section{INSERT Table 3.3 and Table 3.4}

In the case of non-production workers, there were factor content net-exports of 378,000 production workers in the year 2000 , which represents $10.9 \%$ of the total of non-production workers $(3,456,000)$ in manufacturing in 1990. Compared with trade patterns in 1980 , net-exports of non-production workers have increased by 89,000 , which is equivalent to $2.6 \%$ of the total of non-production workers in 1990. The major increase in this factor content occurred in Japan's trade with the US (Table 3.4).

In the case of land, factor content net-exports in 2000 amounted to 1.36 trillion yen (in 1990 prices), which is equivalent to $10.5 \%$ of the total land value (12.9 trillion yen) used in 
manufacturing in 1990. Net exports of land have gradually declined over the last twenty years (Table 3.4).

Capital stock factor content net-exports in 2000, meanwhile, stood at 9.12 trillion yen (in 1990 prices), which represents $16.5 \%$ of the total capital stock (55.4 trillion yen) in manufacturing in 1990 . Compared with 1980, this represent an increase in net-exports of capital stock by 1.1 trillion yen or $2.0 \%$ of the total capital stock in 1990 (Table 3.4).

Relative to the total amount of each of the four primary input factors used in manufacturing, Japan exported a large amount of capital and non-production labor but only a small amount of production labor in 2000. Since non-production workers on average are more educated than production workers and Japan is a country abundant in physical and human capital, the above results are consistent with the Heckscher-Ohlin theory.

As Table 3.3 shows, in the period from 1980-2000, Japan's factor content net-exports of production workers fell by $3.3 \%$, while net-exports of non-production workers rose by $2.6 \%$. This change in trade patterns has the effect of increasing the implied supply-ratio of production/non-production workers available to the manufacturing sector for other use by about $5.9 \%$. More than one-half of this change (3.2\%) was caused by Japan's trade with China and Hong Kong.

During 1980-2000, Japan's factor content net-exports of capital stock grew by $2.0 \%$, while net-exports of workers overall (production and non-production) decreased by $1.5 \%$. This change in the trade pattern has the effect of reducing the implied supply of capital stock per worker available to the manufacturing sector for other use by $3.5 \%$. Thus, compared with the impact on the implied supply ratio of production/non-production workers, the effect of recent changes in trade patterns on the implied supply of capital stock per worker has been small.

By a similar calculation using the results of the factor content analysis at the 4-digit level 
carried out by Feenstra and Hanson (2000), we can evaluate the impact of US trade on its factor markets. This shows that in the period of 1982-94, changes in US trade patterns had the effect of increasing the implied supply ratio of production/non-production workers available to the manufacturing sector for other use by $1.0 \%$, while the implied supply of capital stock per worker available to the manufacturing sector for other use fell by $2.3 \%{ }^{12}$ Thus, compared with the US, Japan experienced a much more drastic change in factor content net-exports over the last two decades in terms of its implied supply ratio of production/non-production workers available to the manufacturing sector for other use.

The trends shown here mean that, Japan's factor content net-exports have changed in a direction that offsets the effect of the accumulation of physical and human capital per capita. Japan has come to export more physical and human capital intensive products over the past two decades. However, compared with the rapid deepening of physical and human capital in the macro-economy described in Section 2, the offsetting effect of international trade seems to be small. Table 3.5 compares physical and human capital deepening in the Japanese manufacturing sector as a whole with that purely attributable to changes in factor contents of trade. Although the average annual growth rate of capital-labor ratio for the manufacturing sector total is $7.60 \%$ for the $1980-1998$ period, the growth rate becomes very small at $0.18 \%$ when we only take account of change in factor contents of trade. As for the growth rate of the share of non-production workers, the offsetting effect of international trade is also small for the 1980-1990 period and throughout the 1980-2000 period. However, in the 1990s, the contribution of international trade to the growth of the share of non-production workers in the Japanese manufacturing sector is much larger, which implies a

${ }^{12}$ In the period of 1982-94, the United States saw an increase in its factor content net-imports of production (non-production) workers in manufacturing of 8.2\% (7.2\%). It also experienced a rise in factor content net-imports of capital stock in manufacturing of 5.5\% and a decline in net-exports of (production plus non-production) workers of $7.8 \%$ of total workers in manufacturing. 
significant effect of international trade on Japan's human capital deepening.

INSERT Table 3.5

\section{Japan's Intra-Industry Trade and Determinants of Factor Intensity within Industry}

So far, we have found that the macro-level capital-labor ratio has been increasing over the last two decades, and that most of the increase is attributable to the within-industry shift and not the between-industry shift. Moreover, most of the macro-level increase in the skilled or non-production labor share in the total number of workers has also been induced by the within-industry shift. As has been argued in previous studies, the international division of labor through the fragmentation of production processes and the import of unskilled labor-intensive intermediate inputs may have contributed to an increase in the relative demand for skilled labor in each industry. That is, if firms fragment their production into discrete activities and move non-skill-intensive activities abroad, then trade will shift employment toward skilled workers within those industries. This type of international division of labor has been referred to as "outsourcing" in the recent literature. Feenstra and Hanson (1996a, 1996b, 1999) and Hijzen, Görg and Hine (2003), for example, provide econometric evidence of a positive relationship between outsourcing and the demand for skilled labor. Although the international fragmentation of production has been increasing rapidly in Japan in recent years, too, contributing to changes in trade patterns, studies analyzing the impact of fragmentation on labor and capital are very limited. ${ }^{13}$

Moreover, vertical intra-industry trade (VIIT), i.e. intra-industry trade where goods are differentiated by quality, may have a large impact on factor demands within each manufacturing industry in Japan. As Falvey (1981) pointed out in his seminal theoretical paper, commodities of the

\footnotetext{
13 An exception is Sakurai (2000), who conducts a similar analysis for Japan. See section 4.2 for the details.
} 
same statistical group but of different quality may be produced using different mixes of factor inputs. Therefore, developed economies like Japan may export physical and human capital-intensive products of high-quality and import unskilled labor-intensive products of low quality from developing economies. As a result, an increase in VIIT may also raise the physical and human capital intensity in Japan.

In the following subsections, we briefly outline the changes in outsourcing and VIIT patterns by industry in Japan for the period from $1988-2000 .{ }^{14}$ We also discuss the relationship between changes in factor demand and trade patterns by industry. Using industry-level as well as firm-level data, we conduct econometric analyses to investigate the determinants of the observed growth in the skilled-labor share in total workers and in the capital-labor ratio. We should note that following analyses are limited to the manufacturing sector due to data constraints.

\subsection{Industry-Level Overview of Fragmentation and Factor Intensity}

Japan's trade patterns have undergone various changes over time: in particular, the share of trade with Asian countries in overall trade has increased markedly. In this subsection, utilizing Japan's customs data and the JIP database, we investigate VIIT and outsourcing from foreign countries by industry, and analyze the impacts of these trends on shift in factor demand in Japan.

Figure 4.1 shows the share of VIIT, a broad outsourcing measure, and a narrow outsourcing measure by industry for the year 2000, while Figure 4.2 presents the average annual growth rates of these values from 1988-2000 by industry. ${ }^{15}$ Following major preceding studies such as Greenaway, Hine, and Milner (1995) and Fontagné, Freudenberg, and Péridy (1997), our VIIT measure is

14 As for the capital-labor ratio, due to data constraints, our analysis focuses only on the period from 1988-98.

15 For the definition of VIIT and broad and narrow outsourcing measures, see Appendix. For more detailed analyses on VIIT in Japan and East Asia, see Fukao, Ishido, and Ito (2003). 
calculated based on the assumption that the gap between the unit value of imports and the unit value of exports for each commodity reveals the qualitative differences of the products exported and imported between the two countries. Our measures of broad and narrow outsourcing are constructed following Feenstra and Hanson (1999). The broad outsourcing measure expresses imported intermediate inputs relative to total expenditure on non-energy intermediate inputs in each industry. The narrow outsourcing measure is expressed by the imported intermediate inputs purchased from the same JIP industry as the good being produced divided by the total expenditure on non-energy intermediate inputs in each industry. Figure 4.1 shows that the level of the VIIT share in the year 2000 was relatively high (more than 30 percent) in publishing and printing, other chemicals, metal products, electrical machinery, other electrical machinery, and precision machinery and equipment. On the other hand, the broad outsourcing measure was high (more than 15 percent) in food products (livestock products and processed marine products), apparel and accessories, lumber and wood products, leather and leather products, basic chemicals, chemical fibers, non-ferrous metals, other electrical machinery, and precision machinery and equipment. The narrow outsourcing measure was high (more than 5 percent) in food products (livestock products and processed marine products), lumber and wood products, pulp, paper, and paper products, leather and leather products, basic chemicals, petroleum products, steel manufacturing, non-ferrous metals, other electrical machinery, other transportation equipment, and precision machinery and equipment. Figure 4.2 shows that the VIIT share and outsourcing measures increased in most manufacturing sectors during the period from 1988-2000. In particular, we find that the outsourcing measures increased relatively more in food products, textile products, and machineries, while the VIIT share increased relatively more in food products, textile products, petroleum and coal products, non-ferrous metals and motor vehicles.

\section{INSERT Figure 4.1 and Figure 4.2}

Next, let us look at the correlations between changes in factor intensities, the VIIT share, and 
the outsourcing measures. Table 4.1 summarizes the correlation coefficients between the annual growth rates of the shares of skilled workers, non-production workers, the VIIT share, and the broad and narrow outsourcing measures for the period from 1988-2000. Although we can see a positive correlation between skilled workers' share and the VIIT share, the correlation coefficient is not statistically significant. Moreover, the correlation coefficients between the capital-labor ratio and the VIIT share and between non-production workers' share and the VIIT share are negative, though not significant. As for changes in the outsourcing measures and factor intensities, a significantly positive correlation can be seen only in the case of skilled workers' share. Therefore, the simple correlation coefficient analysis does not provide strong support for the conjecture that outsourcing or VIIT may have contributed to physical and human capital deepening in each industry.

\section{INSERT Table 4.1}

\subsection{Econometric Analysis}

In this section, we conduct a statistical analysis of the determinants of factor intensities using the industry-level data from 1988-2000. Several previous studies have analyzed the impact of fragmentation on skill upgrading (human capital deepening). Using detailed industry-level data for the US, Feenstra and Hanson (1996a, 1996b, 1999) estimate the effect of international outsourcing on wage inequality. Hijzen, Görg and Hine (2003) conduct a similar analysis using UK data for 53 manufacturing industries for the period from 1982-1997. As for Japan, Sakurai (2000) analyzes this issue using data for 39 manufacturing industries for the period from 1987-1990. While the studies on the US and the UK found a strong positive relationship between outsourcing and wage inequality, Sakurai's (2000) study on Japan did not produce such clear-cut evidence. Sakurai explains that his ambiguous result might be due to the short estimation period. The present paper aims at applying and extending the Feenstra and Hanson approach by using JIP industry-level data (35 manufacturing 
industries) for the period from 1988-2000. In addition, we take account of the role of skill-biased technological change (SBTC) in the increase in skilled (non-production) worker intensity, utilizing the JIP IT (Information Technology) database. ${ }^{16}$ As Hijzen, Görg and Hine (2003) mention, the inclusion of the 1990s in the analysis is thought to be crucial as international fragmentation and information technology progressed rapidly in the past decade. However, one drawback of our analysis is that we cannot calculate wage bills for skilled (non-production) and unskilled (production) workers due to data constraints. Therefore, we assume that the relative wage rates of skilled (non-production) and unskilled (production) workers have not changed over time, and we use the ratio of the number of skilled (non-production) workers to the total number of workers as a proxy for the share of skilled (non-production) workers' wage bill in the total wage bill.

A translog cost function approach, based on the work of Berman, Bound and Griliches (1994) and Feenstra and Hanson (1996b), is usually employed in the literature to estimate skill upgrading and we follow this approach here. Similarly, following previous studies, we consider capital as a fixed input in the short-run, while skilled and unskilled (non-production and production) workers are variable factors of production. Therefore, the short-run translog cost function can be presented as:

$$
\begin{array}{r}
\ln C_{i}=\alpha_{0}+\sum_{j=1}^{J} \alpha_{j} \ln w_{i j}+\sum_{k=1}^{K} \beta_{k} \ln x_{i k}+\frac{1}{2} \sum_{j=1}^{J} \sum_{s=1}^{J} \gamma_{j s} \ln w_{i j} \ln w_{i s} \\
+\frac{1}{2} \sum_{k=1}^{K} \sum_{l=1}^{K} \delta_{k l} \ln x_{i k} \ln x_{i l}+\sum_{j=1}^{J} \sum_{k=1}^{K} \varphi_{j k} \ln w_{i j} \ln x_{i k}
\end{array}
$$

where $C_{i}$ is the variable cost for industry $i, w_{i j}$ denotes the wages of workers in skill group $j$, and $x_{i k}$ denotes the fixed inputs or outputs $k$. Differentiating the translog cost function with respect to wages

${ }^{16}$ According to the argument put forward by Feenstra and Hanson (1999), both skill-biased technological change and outsourcing can be considered to be associated with within-industry changes in skill intensity as a result of their effect on the relative productivity of different skill groups. That is, as fragmentation or outsourcing take the form of moving unskilled labor-intensive processes from a developed country to a developing country, they have a similar effect as technological change. 
yields the factor payments to skill group $j$ over the total wage bill.

$$
S_{i j}=\alpha_{j}+\sum_{s=1}^{J} \gamma_{j s} \ln w_{i j}+\sum_{k=1}^{K} \varphi_{j k} \ln x_{i k}
$$

Assuming that quality-adjusted wages will be identical across industries, the wage terms can be dropped from the right-hand-side of the equation (4.2). We consider technological change, VIIT, and outsourcing as structural variables and assume there are three kinds of capital, i.e., IT hardware, IT software, and non-IT capital. A full set of year dummies is included in order to capture economy-wide skill upgrading as well as year-to-year changes in the wage levels faced by all industries. Therefore, we estimate the following equation:

$$
\begin{aligned}
S_{i j t}= & \varphi_{j 0}+\varphi_{j 1} \ln (\text { IThard } / V A)_{i t}+\varphi_{j 2} \ln (\text { ITsoft } / V A)_{i t}+\varphi_{j 3} \ln (\text { NonIT /VA })_{i t} \\
& +\varphi_{j 4} \ln V A_{i t}+\varphi_{j 5}(R D \exp / V A)_{i t}+\varphi_{j 6} \text { VIIT }_{i t}+\varphi_{j 7} \text { Outsourcing }_{i t}+\varphi_{j 8} D_{t} \\
& +v_{i}+\varepsilon_{i t}
\end{aligned}
$$

where IThard, ITsoft, and NonIT denote IT hardware stock, IT software stock, and non-IT capital stock, respectively; $V A$ is value added in industry $i, R D \exp / V A$ is a proxy for technological change calculated as expenditure on research and development over value added, VIIT represents the VIIT value over industry $i$ 's shipment, Outsourcing reflects either broad or narrow outsourcing, and $D$ is a full set of year dummies. Subscript $t$ represents time. In order to examine different effects of VIIT with Asian countries and VIIT with other countries, we prepare three variables representing VIIT: first, Japan's VIIT with all countries in the world divided by the industry's shipment; second, Japan's VIIT with nine Asian countries divided by the industry's shipment; and third, Japan's VIIT with all the countries except for the nine Asian countries divided by the industry's shipment. ${ }^{17}$

In addition, using the industry-level data, we examine whether the international division of

${ }^{17}$ For more details on the definition of the variables and data sources, see Appendix. 
labor contributed to physical capital deepening in Japan. We use the capital-labor ratio (physical capital stock divided by number of workers, $K L$ ) as the dependent variable and regress it on the logarithm of the wage rate relative to the rental price of capital (ln(wage/rental price)) and variables representing the degree of the international division of labor.

The results of the GLS estimation are presented in Table 4.2. This shows that the estimated coefficients on $\ln (I T h a r d / V A), \ln (V A)$, and $R D \exp / V A$ are significantly positive in all cases where skilled workers' share (SKILLED) or non-production workers' share (NONPROD) in the total number of workers is used as the dependent variable (columns (1) to (4)). The results imply that: 1) IT hardware intensity has a positive impact on skill upgrading, and skill-biased technological change may have increased the share of skilled (non-production) workers; 2) the scale-effect is positive and greater value-added is associated with a higher skilled (non-production) workers' share; and 3) R\&D intensity which is a proxy for technological change, has a positive impact on skill upgrading. On the other hand, a significantly negative coefficient is obtained for $\ln (N o n I T / V A)$ in all the cases but one for columns (1) to (4), which suggests that increases in non-IT capital intensity favor unskilled (production workers) in Japan. As for IT software intensity, the estimated coefficients are positive in columns (1) and (2) but negative in columns (3) and (4), though they are not statistically significant in any of the cases.

As for the VIIT share, the estimated coefficients are significantly positive in columns (1) and (2) but statistically insignificant in columns (3) and (4), suggesting that VIIT raises the skill-intensity calculated as the share of workers whose occupation is classified as professional and technical or managerial and administrative. Moreover, looking at the magnitude of the coefficients in column (2), VIITasia9/shipment has a much larger coefficient than VIITnon-asia9/Shipment. This may reflect the fact that vertical FDI in the Asian countries tends to consist of the transfer of low-skill production work to these countries while high-skilled employees remain at home. We can confirm that Japanese 
manufacturing industries realized skill upgrading as a result of the international division of labor with the nine Asian countries. When the skill-intensity is calculated as the share of non-production workers, however, VIIT does not have a significant impact on skill upgrading though the estimated coefficient on VIIT is positive in columns (3) and (4). This result might be a reflection of the fact that Japanese firms reduced the share of non-production and non-professional workers (such as sales persons) in the course of the restructuring efforts during the 1990s.

Although narrow outsourcing has a positive coefficient and the difference between broad and narrow outsourcing has a negative coefficient in columns (1) to (4), none of coefficients are significant. We could not find strong evidence that outsourcing to foreign countries contributed to skill upgrading in Japan, which is not consistent with the results of previous studies on the United States and the United Kingdom.

As for the capital-labor ratio (column (5)), none of the explanatory variables except for the VIIT variable have statistically significant coefficients. Although VIITworld/shipment has a significantly positive coefficient, the small value of the Wald-statistics indicates the weak explanatory power of the equation. Again, we could not obtain strong evidence that VIIT and outsourcing contributed to physical capital deepening in Japan, suggesting that capital deepening was caused by other factors.

INSERT Table 4.2

\section{Conclusion}

Our goal in this paper has been to investigate the changing trade patterns and their effect on factor intensities in Japan, mainly focusing on the manufacturing sector. Given the observation that the capital-labor ratio and the share of skilled workers in the total number of workers have been growing for the last couple of decades, we first conducted decomposition analyses and found that 
most of the macro-economic change in the capital-labor ratio and the change in the skilled-labor ratio were attributable to a within-industry shift rather than a between-industry shift. The between-industry shift can be partly explained by the change in patterns of inter-industry trade which affects the size of each industry. However, the large within-industry effect led us to suspect that the division of labor and intra-industry trade between Japan and Asian countries may have contributed to the within-industry increase in capital intensity and skilled-labor intensity. Therefore, we first analyzed factor contents of trade from the aspect of inter-industry trade, and then analyzed whether the deepening of the international division of labor and vertical intra-industry trade contributed to the within-industry change in factor intensities in Japan.

We found that Japan's factor content net-exports of capital and non-production labor grew rapidly while net-exports of production workers fell by a large amount. Interestingly, the decline in the factor content of net-exports of production workers was almost entirely caused by Japan's trade with China and Hong Kong. Although international trade to a considerable extent contributed to the growth in the share of non-production workers in the Japanese manufacturing sector as a whole, most of the macro-level accumulation of physical capital was not offset by the growth in factor content net-exports of physical capital.

Although we clearly saw a drastic increase in VIIT and outsourcing to foreign countries, particularly to Asian countries, our empirical analysis provided only weak evidence that the deepening international division of labor contributed to the change in factor intensities in Japan. We did not find a significant and robust positive relationship between fragmentation and capital-labor ratios. As for skill intensity, we found that VIIT had a strong positive effect on the increase in the share of skilled workers when these were defined as those holding professional and technical or managerial and administrative occupations. However, we did not find such a relationship when the skill-intensity was calculated as the share of non-production workers. We should note that the skilled 
(professional, technical, managerial, and administrative) labor share in the total number of workers is only around $10 \%$ and is much lower than the share of non-production workers which is around $30 \%$. According to our results, specialization in the export of skilled-labor-intensive products may have contributed to the increase in the relative demand for skilled (professional, technical, managerial, and administrative) labor within industry. However at the same time, our results could also imply that changes in trade patterns (specialization in capital-intensive production) did not offset the excess supply of capital in Japan. Probably one plausible explanation for this small offsetting effect might be that VIIT or fragmentation patterns are not determined by the abundance of capital endowments, but by other factors such as endowments with skilled labor, the agglomeration of industries, highly-developed supporting industries, etc. Davis and Weinstein (2003), who empirically tested the determinants of the firm-level trade patterns, conclude that after controlling for national factor accumulation, firm level export decisions seem to have little correlation with the capital intensity of their production process. We do not know yet whether this story applies to the case of industry-level trade patterns and which factors matter for trade patterns. This is, however, an issue that deserves closer scrutiny in future investigations. 


\section{Appendix. Definition of Variables Used in the Econometric Analysis and Data Sources}

\section{Labor data}

Data on skilled and unskilled labor were constructed mainly using the Population Census of Japan, published by Statistics Bureau, Ministry of Public Management, Home Affairs, Posts, and Telecommunications. The Population Census is the most fundamental and reliable survey and is conducted every five years, covering all permanent and temporary residents in Japan. The survey report provides data on employment by detailed occupational classification (3-digit-level) and by industry. We used the 1980, 1985, 1990, and 1995 employment data as benchmarks and interpolated the data for years between the benchmarks. As for the years after 1995, we utilized the Employment Status Survey data, published by Statistics Bureau, Ministry of Public Management, Home Affairs, Posts, and Telecommunications, because the results of the 2000 Population Census have not been released yet. The Employment Status Survey is based on a series of surveys that cover approximately one percent of the working population. We first calculated the skilled labor share for 1992, 1997, and 2002 based on the Employment Status Survey. Then, for the 1996 and 1997 data on skilled labor, we extended the 1995 employment data by occupation and industry using the growth rate of the skilled labor share from 1992 to 1997. For the 1998, 1999 and 2000 data, we extended the 1997 data using the growth rate of the skilled labor share from 1997 to 2002. The Population Census and the Employment Status Survey allow us to construct a measure of skill that is more accurate than the one based on production and non-production labor generally used in preceding studies. In the Population Census and the Employment Status Survey, workers are basically classified according to 10 Major Groups as shown in Appendix Table 1. We distinguished two skill groups (skilled or unskilled) as well as production/non-production classifications. Skilled workers are those classified in Major Groups 1 (Professional and Technical Occupations) and 2 (Managers and Administrators). Otherwise, 
workers are classified as unskilled. Moreover, production workers are those classified in Major Group 9 (Plant and Machine Occupations, Craft and Related Occupations, and Occupations in Mining and Construction). Workers classified in all the other Major Groups are categorized as non-production workers.

\section{INSERT Appendix Table 1}

\section{Measurement method and data source for vertical intra-industry trade}

In order to identify vertical and horizontal IIT we adopt a methodology used by major preceding studies on vertical IIT such as Greenaway, Hine, and Milner (1995) and Fontagné, Freudenberg, and Péridy (1997). The methodology is based on the assumption that the gap between the unit value of imports and the unit value of exports for each commodity reveals the qualitative differences in the products exported and imported between the two economies.

We break down the bilateral trade flows of each detailed commodity category into the following three patterns: (a) inter-industry trade (one-way trade), (b) intra-industry trade (IIT) in horizontally differentiated products (products differentiated by attributes), and (c) IIT in vertically differentiated products (products differentiated by quality). Then the share of each trade type is defined as:

$$
\frac{\sum_{j}\left(M_{k k^{\prime} j}^{Z}+M_{k^{\prime} k j}^{Z}\right)}{\sum_{j}\left(M_{k k^{\prime} j}+M_{k^{\prime} k j}\right)}
$$

where the variables are defined as

$$
\begin{aligned}
& M_{k k^{\prime} j}: \text { value of economy } k^{\prime} \text { s imports of product } j \text { from economy } k^{\prime} ; \\
& M_{k^{\prime} j^{\prime}} \text { : value of economy } k^{\prime \prime} \text { s imports of product } j \text { from economy } k \text {; } \\
& U V_{k k^{\prime} j} \text { : average unit value of economy } k^{\prime} \text { s imports of product } j \text { from economy } k^{\prime} \text {; } \\
& U V_{k^{\prime} j j}: \text { average unit value of economy } k^{\prime \prime} \text { s imports of product } j \text { from economy } k \text {. }
\end{aligned}
$$


The upper-suffix $Z$ denotes one of the three intra-industry trade types, i.e., "One-Way Trade" (OWT) "Horizontal Intra-Industry Trade" (HIIT) and "Vertical Intra-Industry Trade" (VIIT) as in Appendix Table 2.

For our analysis, we chose to identify horizontal IIT by using the range of relative export/import unit values of $1 / 1.25$ (i.e., 0.8 ) to 1.25 .

Appendix Table 2. Categorization of trade types

\begin{tabular}{|l|l|c|}
\hline \multicolumn{1}{|c|}{ Type } & Degree of trade overlap & Disparity of unit value \\
\hline “One-Way Trade” & $\frac{\operatorname{Min}\left(M_{k k^{\prime} j}, M_{k^{\prime} k j}\right)}{\operatorname{Max}\left(M_{k k^{\prime} j}, M_{k^{\prime} k j}\right)} \leq 0.1$ & Not applicable \\
\hline “Horizontal $\quad$ Trade" & $\frac{\operatorname{Min}\left(M_{k k^{\prime} j}, M_{k^{\prime} k j}\right)}{\operatorname{Max}\left(M_{k k^{\prime} j}, M_{k^{\prime} k j}\right)}>0.1$ & $\frac{1}{1.25} \leq \frac{U V_{k k^{\prime} j}}{U V_{k^{\prime} k j}} \leq 1.25$ \\
(HIIT) & $\frac{\operatorname{Min}\left(M_{k k^{\prime} j}, M_{k^{\prime} k j}\right)}{\operatorname{Max}\left(M_{k k^{\prime} j}, M_{k^{\prime} k j}\right)}>0.1$ & $\frac{U V_{k k^{\prime} j}}{U V_{k^{\prime} k j}}<\frac{1}{1.25}$ or $1.25<\frac{U V_{k k^{\prime} j}}{U V_{k^{\prime} k j}}$ \\
\hline "Vertical Intra-Industry & & \\
\hline
\end{tabular}

We used Japan's customs data provided by the Ministry of Finance (MOF). Japan's customs data are recorded at the 9-digit HS88 level and the data classified by HS88 are available from the year 1988. The 9-digit HS88 code has been changed several times for some items, and the HS code was revised in 1996. Using the code correspondence tables published by the Japan Tariff Association for code changes, we made adjustments to make the statistics consistent with the original HS88 code. In Japan's customs statistics, export data are recorded on an f.o.b. basis while import data are on a c.i.f. basis. We should note that our estimate of the VIIT share is biased upward because of this difference. 


\section{Outsourcing measures}

Following Feenstra and Hanson (1999) and other previous studies, we constructed outsourcing measures as follows:

For each industry $i$, we measure imported intermediate inputs as

$\Sigma_{j}[\text { input purchases of good } j \text { by industry } i]^{*}[(\operatorname{imports}$ of $\operatorname{good} j) /(\operatorname{consumption}$ of $\operatorname{good} j)]$

where consumption of good $j$ is measured as (shipments + imports - exports). The broad measure of foreign outsourcing is obtained by dividing imported intermediate inputs by total expenditure on non-energy intermediate inputs in each industry. The narrow measure of outsourcing is obtained by restricting attention to those inputs that are purchased from the same JIP industry as the good being produced. Using Japan's customs data, Hiromi Nosaka, Tomohiko Inui, Keiko Ito, and Kyoji Fukao compiled trade data at the basic industry classification of the I-O tables in 1990 prices as part of the Japan Industrial Productivity (JIP) database project at the Economic and Social Research Institute, Cabinet Office, Government of Japan. The correspondence between the Fukao-Ito industry classification and the 1980-85-90 Japan Linked Input-Output standard classification for manufacturing industries is presented in Appendix Table 3. The correspondence between the JIP classification and the Fukao-Ito classification for manufacturing industries is presented in Appendix Table 4. When calculating the outsourcing measures, we first calculated the input coefficients by Fukao-Ito industry and aggregated the imported intermediate inputs in each Fukao-Ito industry into the corresponding JIP industry. As for the narrow outsourcing measure, we restricted the Fukao-Ito industry subscripts $i$ and $j$ in equation (A2) to be within the same JIP industry. We should note that we only took account of intermediate inputs from manufacturing industries.

INSERT Appendix Tables 3 and 4 


\section{Other variables used in the industry-level econometric analyses}

\section{IT hardware (million yen, 1990 prices)}

We mainly used IT hardware stock data in the JIP database. For details on the JIP database, see Fukao, Inui, Kawai, and Miyagawa (2003). Tangible IT assets (hardware) include office machines, computers, computer peripherals, communications equipment, optical instruments and medical instruments. As only data until 1998 are available in the JIP database, we extended the IT hardware stock until 2000 by using the annual growth rate of real IT hardware stock from 1998 to 2000 in JCER (Japan Center for Economic Research) IT data. ${ }^{18}$

\section{IT software (million yen, 1990 prices)}

We constructed industry-level software stock data using the JIP database, the JCER IT data, and software investment data underlying Motohashi (2002) and Jorgenson and Motohashi (2003). ${ }^{19}$ The JCER data provide real software stock by 2-digit industry but include only order-made software. In the JIP database, real software stock data which cover in-house software and general application software as well as order-made software are available until 1999. Therefore, we first divided the JIP software stock value at the macro-level into each 2-digit industry using the distribution ratios in the JCER IT data. Then, we further divided it into the JIP industry classification, using the distribution ratios of IT hardware by JIP industry. Since the JIP software stock data are available only until 1999, for the year 2000, we calculated the macro-level real software stock, using Motohashi's software investment data and software deflators.

\section{Non-IT physical capital stock (million yen, 1990 prices)}

Physical capital stock data including IT hardware stock by industry are available in the JIP

${ }^{18}$ We wish to thank Professor Tsutomu Miyagawa at Gakushuin University and Ms. Yukiko Ito at the Japan Center for Economic Research for providing the JCER IT data.

${ }^{19}$ We are also grateful to Dr. Kazuyuki Motohashi at Hitotsubashi University for providing the data. 
database until 1998. We extended the data up to 2000 by using the investment data in METI's Report on Industry Statistics, which is based on the Census of Manufactures. First, we aggregated the data on investment in fixed assets in the Report on Industry Statistics into the JIP industry-level and then deflated them using the gross domestic capital formation deflator (plant and equipment) in the Annual Report on National Accounts released by the Cabinet Office, Government of Japan. We assumed a depreciation rate of 10 percent and estimated the real physical capital stock for 1999 and 2000. Non-IT physical stock is defined as physical capital stock minus IT hardware stock.

Value added (million yen, 1990 prices)

We used value added data in the JIP database up to 1998. The data for 1999 and 2000 were constructed using the SNA Input-Output Tables released by the Cabinet Office, Government of Japan.

\section{R\&D expenditure (million yen, 1990 prices)}

We used R\&D expenditure data in the JIP database up to 1998 . We extended the data up to 2000 using the Report on the Survey of Research and Development, Ministry of Public Management, Home Affairs, Posts and Telecommunications. The deflators were taken from the Annual Report on the Promotion of Science and Technology, Ministry of Education, Science, Sports and Culture.

\section{VIIT (\%)}

The variable VIIT is defined as the share of vertical intra-industry trade in total trade values. For our definition of vertical intra-industry trade and data sources, see Appendix 2.

\section{VIITworld/Shipment (\%)}

This variable is calculated as (VIIT*(exports+imports)/2/domestic shipment). VIITworld takes account of Japan's trade with all countries in the world. Data on domestic shipments were taken from the JIP database up to 1998 and from the SNA Input-Output Tables for 1999 and 2000.

\section{VIITasia9/Shipment (\%)}


This variable is calculated in the same way as VIITworld/Shipment. VIITasia9 takes account of Japan's trade with the following nine Asian countries: China, Korea, Taiwan, Hong Kong, Singapore, Indonesia, Malaysia, the Philippines, and Thailand.

\section{VIITnon-asia/Shipment (\%)}

This variable is calculated in the same way as VIITworld/Shipment. VIITnon-asia takes account of Japan's trade with all countries other than the nine Asian countries.

\section{KL (million yen per person, 1990 prices)}

The capital-labor ratio was calculated using physical capital stock data and data on number of workers taken from the JIP database for 1988-1998.

\section{Wage (1990=1.0)}

The labor quality-adjusted wage index was taken from the JIP database for 1988-1998.

\section{Rental price $(1990=1.0)$}

The rental price index of capital was taken from the JIP database for 1988-1998. 


\section{References}

Berman, Eli, John Bound, and Zvi Griliches (1994) "Changes in the Demand for Skilled Labor within U.S. Manufacturing: Evidence from the Annual Survey of Manufactures," Quarterly Journal of Economics, Vol. 109, pp. 367-98.

Campa, Jose and Linda S. Goldberg (1997) “The Evolving External Orientation of Manufacturing: A Profile of Four Countries," Economic Policy Review, Volume 3, Number 2, pp. 53-81.

Davis, Donald R. and David E. Weinstein (2003) "Why Country Trade: Insights from Firm-Level Data," forthcoming in Journal of the Japanese and International Economies, December 2003.

Falvey, Rodney E. (1981) "Commercial Policy and Intra-Industry Trade," Journal of International Economics, 11, pp. 495-511.

Feenstra, Robert C. and Gordon H. Hanson (1996a) "Foreign Investment, Outsourcing, and Relative Wages," in Robert C. Feenstra, Gene M. Grossman, and Douglas A. Irwin, eds., The Political Economy of Trade Policy, pp. 89-127, Cambridge, Mass. and London: The MIT Press.

Feenstra, Robert C. and Gordon H. Hanson (1996b) "Globalization, Outsourcing, and Wage Inequality," American Economic Review, Vol. 86, pp. 240-245.

Feenstra, Robert C. and Gordon H. Hanson (1999) "The Impact of Outsourcing and High-Technology Capital on Wages: Estimates for the United States, 1979-1990,” The Quarterly Journal of Economics, Vol. 114, Issue 3, pp. 907-940.

Feenstra, Robert C. and Gordon H. Hanson (2000) "Aggregation Bias in the Factor Content of Trade: Evidence from U.S. Manufacturing," AEA Papers and Proceedings, vol. 90, no. 2, pp. $155-160$.

Feenstra, Robert C. and Gordon H. Hanson (2001) "Global Production Sharing and Rising 
Inequality: A Survey of Trade and Wages,” NBER Working Paper No. 8372, July, National Bureau of Economic Research.

Fontagné, Lionel, Michael Freudenberg, and Nicholas Péridy (1997) "Trade Patterns Inside the Single Market,” CEPII Working Paper No. 1997-07, April, Centre D’Etudes Prospectives et D'Informations Internationales.

Fukao, Kyoji, Tomohiko Inui, Hiroki Kawai, and Tsutomu Miyagawa (2003) "Sectoral Productivity and Economic Growth in Japan, 1970-98: An Empirical Analysis Based on the JIP Database," forthcoming in Takatoshi Ito and Andrew Rose, eds., Productivity and Growth, East Asia Seminar on Economics Volume 13, The University of Chicago Press.

Fukao, Kyoji, Hikari Ishido, and Keiko Ito (2003) “Vertical Intra-Industry Trade and Foreign Direct Investment in East Asia," forthcoming in Journal of the Japanese and International Economies, December 2003.

Genda, Yuji (1997) "Japan: Wage Differentials and Changes since the 1980s," in Toshiaki Tachibanali ed. Wage Differentials: An International Comparison, Macmillan Press: London.

Godo, Yoshihisa (2001) "Estimation of Average Years of Schooling by Levels of Education for Japan and the United States, 1890-1990," mimeo, Tokyo: FASID.

Greenaway, David, Robert Hine, and Chris Milner (1995) "Vertical and Horizontal Intra-Industry Trade: A Cross Industry Analysis for the United Kingdom," Economic Journal, Vol.105, November, pp.1505-1518.

Hijzen, Alexander, Holger Görg and Robert C. Hine (2003) "International Fragmentation and Relative Wages in the UK," IZA Discussion Paper Series No. 717, February, Bonn: Institute for the Study of Labor (available at www.iza.org).

Jorgenson, Dale W. and Kazuyuki Motohashi (2003) "Economic Growth of Japan and the United States in the Information Age," RIETI Discussion Paper Series 03-E-015, Tokyo: 
Research Institute of Economy, Trade and Industry.

Jorgenson, Dale W., Mun S. Ho, and Kevin J. Stiroh (2002) "Growth in U.S. Industries and Investments in Information Technology and Higher Education,” paper prepared for NBER/CRIW Conference on Measurement of Capital in the New Economy, April 2002.

Katz, Lawrence F., and Ana L. Revenga (1989) "Changes in the Structure of Wages: The United States vs. Japan," Journal of the Japanese and International Economies, vol. 3, pp. $522-553$.

Kimura, Fukunari (2001) "Fragmentation, Internalization, and Inter-firm Linkages: Evidence from the Micro Data of Japanese Manufacturing Firms,” in Leonard K. Cheng and Henryk Kiezkowski, eds., Global Production and Trade in East Asia, Norwell: Kluwer Academic Publishers.

MITI (Ministry of International Trade and Industry, Government of Japan) (1999) Keizai Hakusho (White Paper on International Trade), Tokyo: MITI.

Motohashi, Kazuyuki (2002) "IT Investment and Productivity Growth in the Japanese Economy and a Comparison to the United States" RIETI Discussion Paper Series 02-J-018, Tokyo: Research Institute of Economy, Trade and Industry (in Japanese).

Pyo, Hak K., and Kwang-Hee Nam (1999) "A Test of the Convergence Hypothesis by Rates of Return to Capital: Evidence from OECD Countries," mimeo, Seoul National University.

Sachs, J. D., and H. J. Shatz (1994) "Trade and Jobs in U.S. Manufacturing," Brookings Papers on Economic Activity, vol. 19, pp. 1-84.

Sakurai, Kojiro (2000) “Gurobaru-ka to Rodo Shijo: Nihon no Seizogyo no Keisu [Globalization and Labor Market: The Case of Japanese Manufacturing],” Keizai Keiei Kenkyu [Economics Today], Vol.21-2, November, Tokyo: Research Institute of Capital Formation, Development Bank of Japan. 
Sakurai, Kojiro (2001) "How Does Trade Affect the Labor Market? Evidence from Japanese Manufacturing," paper presented at the Semi-annual Conference of the Japan Economic Association, October 7-8 ${ }^{\text {th }}, 2001$, Hitotsubashi University. 
Table. 1.1 Sources of Economic Growth: US-Japan Comparison

$<$ Panel A $>$ The Result of Growth Accounting for the US Economy by Jorgenson et al (2002): 1973-2000

\begin{tabular}{|c|c|c|c|c|c|c|c|c|}
\hline & $\begin{array}{l}\text { Real GDP } \\
\text { growth }\end{array}$ & $\begin{array}{l}\text { Man-hour } \\
\text { growth }\end{array}$ & $\begin{array}{l}\text { Labor } \\
\text { productivity } \\
\text { (GDP/man- } \\
\text { hour) growth }\end{array}$ & TFP growth & $\begin{array}{c}\text { Contribution of } \\
\text { labor quality } \\
\text { growth }\end{array}$ & Contribution of & capital sevices $/ \mathrm{m}$ & nan-hour growth \\
\hline & & & & & & Sub-total & \begin{tabular}{|c|}
$\begin{array}{c}\text { Contribution of } \\
\text { IT capital }\end{array}$ \\
\end{tabular} & $\begin{array}{c}\text { Contribution of } \\
\text { non-IT capital }\end{array}$ \\
\hline & $\mathrm{a}$ & $\mathrm{b}$ & $c=a-b$ & $d=c-e-f$ & $\mathrm{e}$ & $\mathrm{f}=\mathrm{g}+\mathrm{h}$ & $\mathrm{g}$ & $\mathrm{h}$ \\
\hline 1973-1995 & $2.78 \%$ & $1.44 \%$ & $1.33 \%$ & $0.26 \%$ & $0.27 \%$ & $0.80 \%$ & $0.37 \%$ & $0.43 \%$ \\
\hline $1995-2000$ & $4.07 \%$ & $1.99 \%$ & $2.07 \%$ & $0.62 \%$ & $0.21 \%$ & $1.24 \%$ & $0.87 \%$ & $0.37 \%$ \\
\hline
\end{tabular}

Jorgenson et al. (2002)

$<$ Panel B $>$ The Result of Growth Accounting for the Japanese Economy: 1973-1998

(annual rate, $\%$ )

\begin{tabular}{|c|c|c|c|c|c|c|c|c|}
\hline & \multirow[t]{2}{*}{$\begin{array}{l}\text { Real GDP } \\
\text { growth }\end{array}$} & \multirow[t]{2}{*}{$\begin{array}{l}\text { Man-hour } \\
\text { growth }\end{array}$} & \multirow[t]{2}{*}{$\begin{array}{c}\text { Labor } \\
\text { productivity } \\
\text { (GDP/man- } \\
\text { hour) growth }\end{array}$} & \multirow[t]{2}{*}{ TFP growth } & \multirow[t]{2}{*}{$\begin{array}{l}\text { Contribution of } \\
\text { labor quality } \\
\text { growth }\end{array}$} & \multicolumn{3}{|c|}{ Contribution of capital services/man-hour growth } \\
\hline & & & & & & Sub-total & $\begin{array}{l}\text { Contribution of } \\
\text { IT capital }\end{array}$ & $\begin{array}{c}\text { Contribution of } \\
\text { non-IT capital }\end{array}$ \\
\hline & $\mathrm{a}$ & $\mathrm{b}$ & $c=a-b$ & $\mathrm{~d}=\mathrm{c}-\mathrm{e}-\mathrm{f}$ & $\mathrm{e}$ & $f=g+h$ & $\mathrm{~g}$ & $\mathrm{~h}$ \\
\hline $1973-83$ & $3.56 \%$ & $1.53 \%$ & $2.03 \%$ & $-0.30 \%$ & $0.65 \%$ & $1.68 \%$ & $0.16 \%$ & $1.52 \%$ \\
\hline 1983-91 & $3.94 \%$ & $1.79 \%$ & $2.15 \%$ & $0.40 \%$ & $0.46 \%$ & $1.29 \%$ & $0.37 \%$ & $0.92 \%$ \\
\hline $1991-98$ & $1.25 \%$ & $-0.08 \%$ & $1.34 \%$ & $0.03 \%$ & $0.21 \%$ & $1.10 \%$ & $0.33 \%$ & $0.76 \%$ \\
\hline & & & & & & 1995-98 & $0.52 \%$ & $0.63 \%$ \\
\hline
\end{tabular}

Source: Fukao et al. (2003), Table 2.2. Original figures are calculated from JIP database. 
Figure 1.1 Japan's Capital-Output Ratio and Rate of Return to Capital: 1973-1998

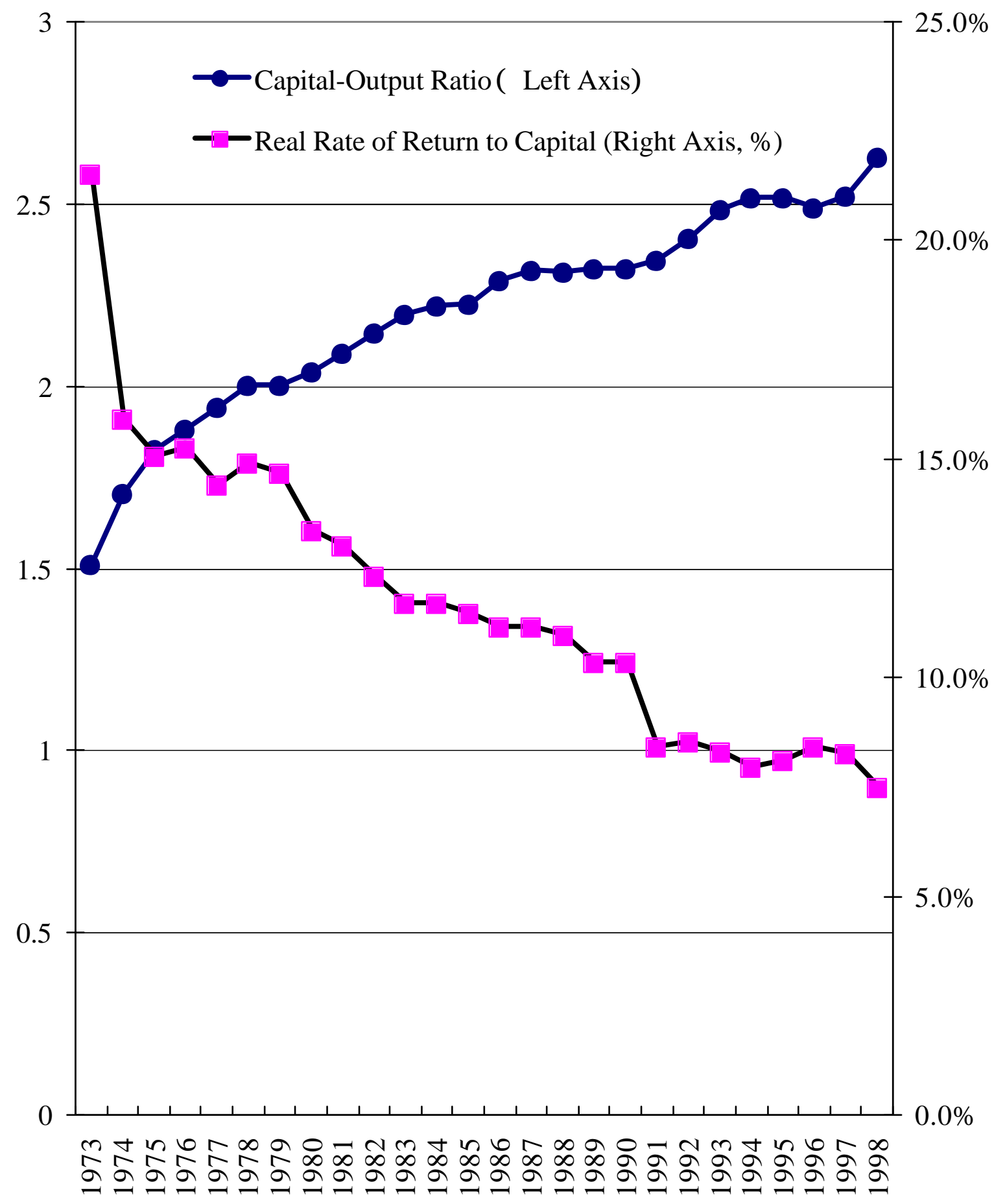

The numerator of the rate of return to capital is the current surplus of the national accounts deflated by the GDP deflator.

Source: JIP Database 
Figure 2.1 Trend of Capital-Labor in Japan

$$
\text { (mil.yen / person) }
$$

$$
18
$$

$18 \longrightarrow$ Real capital stock / Number of total

16 workers in Japan

_ Real capital stock / Number of total manufacturing workers

14

12

10

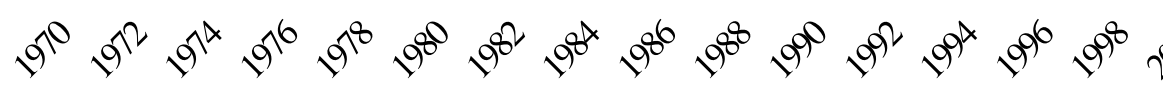

Source: Authors' calculation based on JIP Database.

38 


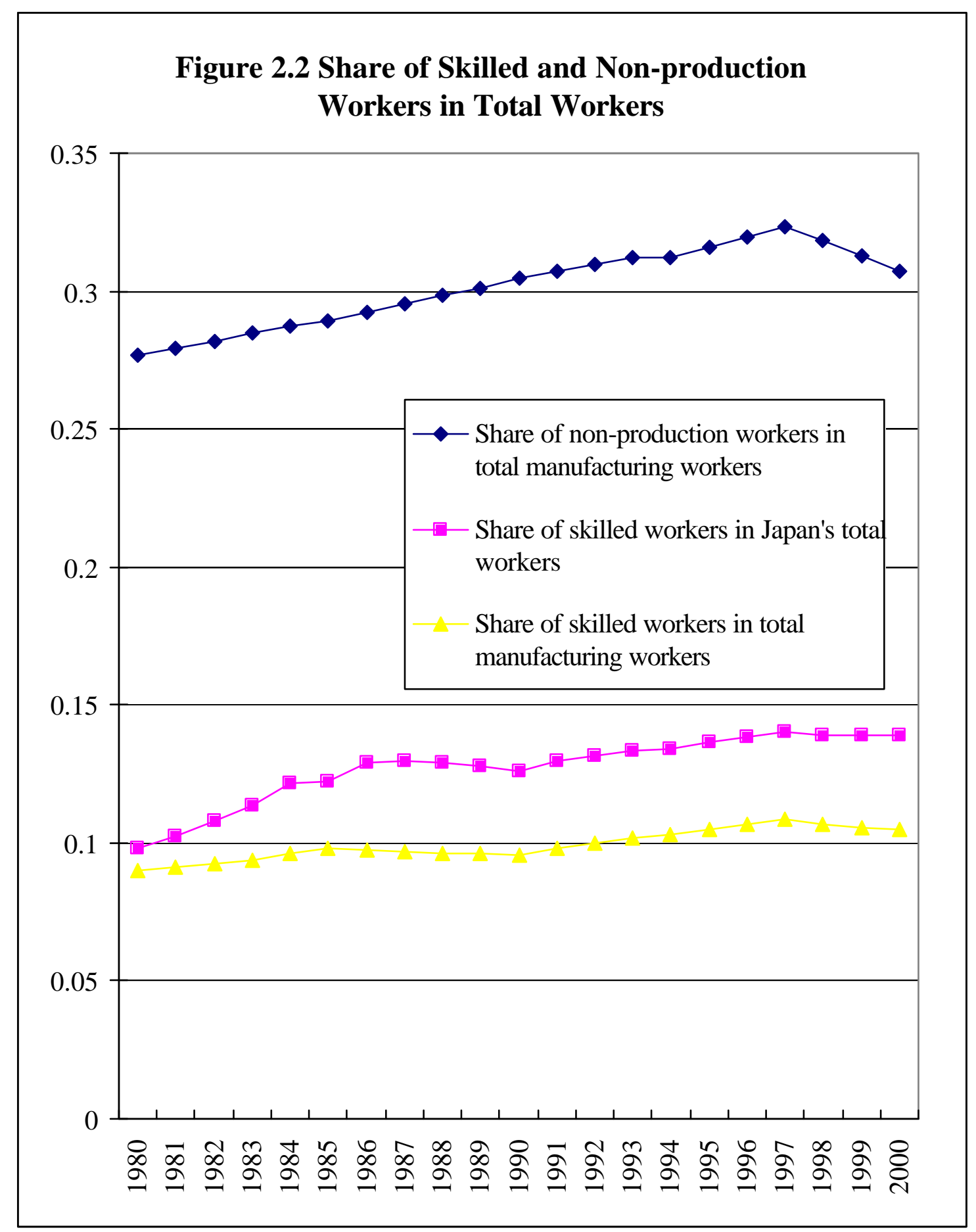

Source: Authors' calculation based on Population Census data. 
Table 2.1 Decomposition of Capital-Labor Ratio Growth

$<$ Panel A> Decomposition of capital-labor ratio growth: manufacturing sector

\begin{tabular}{|l|r|r|r|r|}
\hline & \multicolumn{1}{|c|}{ (annual rate, \%) } \\
\hline Growth rate of K-L ratio & $1970-80$ & $1980-90$ & $1990-2000$ & $1980-2000$ \\
Between effect & -0.45 & 6.43 & 4.18 & 6.65 \\
Within effect & 11.69 & -1.01 & -0.05 & -0.90 \\
& & 7.44 & 4.24 & 7.55 \\
\hline
\end{tabular}

$<$ Panel B> Decomposition of capital-labor ratio growth: the whole economy

\begin{tabular}{|l|r|r|r|r|}
\hline & \multicolumn{3}{|c|}{ (annual rate, \%) } \\
\hline Growth rate of K-L ratio & $1970-80$ & $1980-90$ & $1990-98$ & \multicolumn{1}{c|}{$1980-98$} \\
Between effect & 14.65 & 6.01 & 3.70 & 5.97 \\
& 0.13 & -0.81 & -0.45 & -0.92 \\
Within effect & 14.52 & 6.82 & 4.15 & 6.89 \\
\hline
\end{tabular}

Note: The capital-labor ratio is defined as the real capital stock (in 1990 price) divided by the number of workers. Source: Authors' calculation based on JIP database. 
Table 2.2 Decomposition of the Growth of the Share of Skilled or Non-Production Workers

< Panel A > Decomposition of the growth of the share of non-production workers: manufacturing sector

\begin{tabular}{|l|r|r|r|}
\hline & \multicolumn{3}{c|}{ (annual rate, \%) } \\
\hline Growth rate of the share & $1980-90$ & $1990-2000$ & $1980-2000$ \\
Between effect & 0.12 & 0.08 & 0.55 \\
Within effect & 0.88 & 0.16 & 0.14 \\
& & -0.07 & 0.41 \\
\hline
\end{tabular}

< Panel B> Decomposition of the growth of the share of skilled workers: manufacturing sector

\begin{tabular}{|l|r|r|r|}
\hline & \multicolumn{3}{c|}{ (annual rate, \%) } \\
\hline Growth rate of the share & 0.65 & 0.97 & 0.84 \\
Between effect & 0.29 & 0.25 & 0.27 \\
Within effect & 0.36 & & 0.71 \\
\hline
\end{tabular}

<Panel C> Decomposition of the growth of the share of skilled workers: the whole economy

\begin{tabular}{|c|c|c|c|}
\hline & $1980-90$ & $1990-2000$ & $1980-2000$ \\
\hline Growth rate of the share & 2.88 & 1.03 & 2.10 \\
\hline Between effect & 1.02 & 1.06 & 1.02 \\
\hline Within effect & 1.86 & -0.02 & 1.08 \\
\hline
\end{tabular}

Source: Authors' calculation based on Population Census data and the JIP database. 
Table 3.1 Japan's Share of Imports and Manufacturing Sector in GDP, Employment, and Gross Value Added

\begin{tabular}{|c|c|c|c|c|c|c|}
\hline & $\begin{array}{c}\text { Imports of goods } \\
\text { and } \\
\text { services/GDP }\end{array}$ & $\begin{array}{l}\text { Imports of } \\
\text { manufactured } \\
\text { products } \\
(\mathrm{CIF}) / \mathrm{GDP}\end{array}$ & $\begin{array}{c}\text { Imports of } \\
\text { services/GDP }\end{array}$ & $\begin{array}{c}\text { Share of } \\
\text { manufacturing } \\
\text { sector in total } \\
\text { GDP }\end{array}$ & $\begin{array}{c}\text { Share of } \\
\text { manufacturing } \\
\text { sector in total } \\
\text { employed } \\
\text { persons }\end{array}$ & $\begin{array}{c}\text { Imports of } \\
\text { manufactured } \\
\text { products } \\
\text { (CIF)/gross value } \\
\text { added by } \\
\text { manufacturing } \\
\text { sectoir }\end{array}$ \\
\hline 1980 & $15.1 \%$ & $5.1 \%$ & $1.7 \%$ & $29.2 \%$ & $26.2 \%$ & $17.4 \%$ \\
\hline 1985 & $11.3 \%$ & $4.5 \%$ & $1.6 \%$ & $29.5 \%$ & $26.5 \%$ & $15.2 \%$ \\
\hline 1990 & $9.4 \%$ & $5.3 \%$ & $1.6 \%$ & $28.2 \%$ & $26.2 \%$ & $18.7 \%$ \\
\hline 1995 & $7.8 \%$ & $5.0 \%$ & $1.3 \%$ & $24.7 \%$ & $24.7 \%$ & $20.3 \%$ \\
\hline 2000 & $9.5 \%$ & $6.3 \%$ & $1.3 \%$ & $23.4 \%$ & $22.3 \%$ & $26.7 \%$ \\
\hline
\end{tabular}

Notes: Official SNA statistics for the year 2000 are based on 1993 SNA. For years before 1989, only statistics based on 1968 SNA are available. In order to make long-term comparisons we derived values for 2000 by an extrapolation based on values of 1995 and the 1995-2000 growth rate of each variable reported in SNA statistics based on 1993 SNA.

Sources: Economic and Social Research Institute, Cabinet Office, Government of Japan, Annual Report on National Accounts 2002, Economic Planning Agency, Government of Japan, Annual Report on National Accounts 2000. 


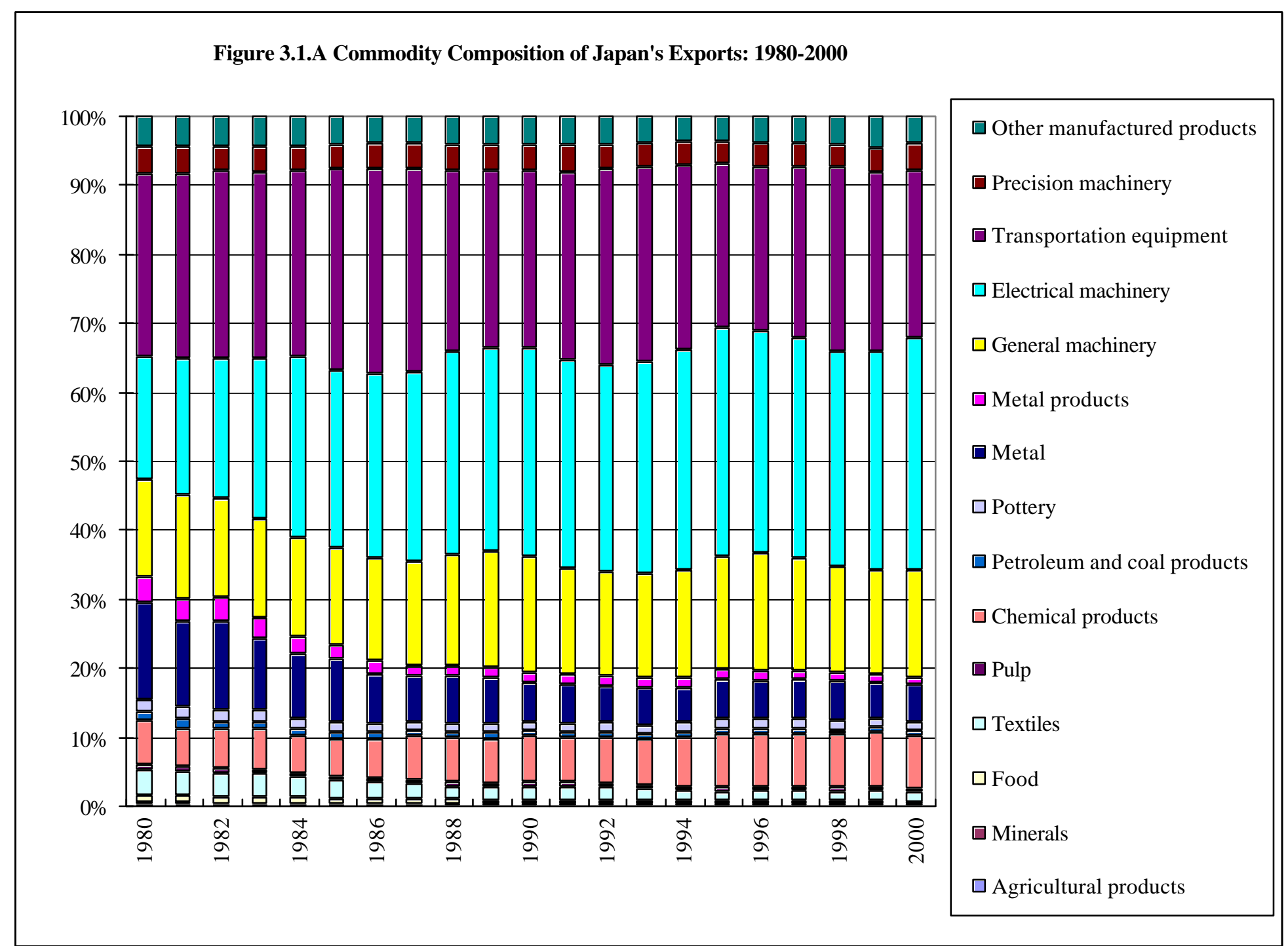

Sources: Economic and Social Research Institute, Cabinet Office, Government of Japan, Annual Report on National Accounts 2002 ,

Economic Planning Agency, Government of Japan, Annual Report on National Accounts 2000 . 


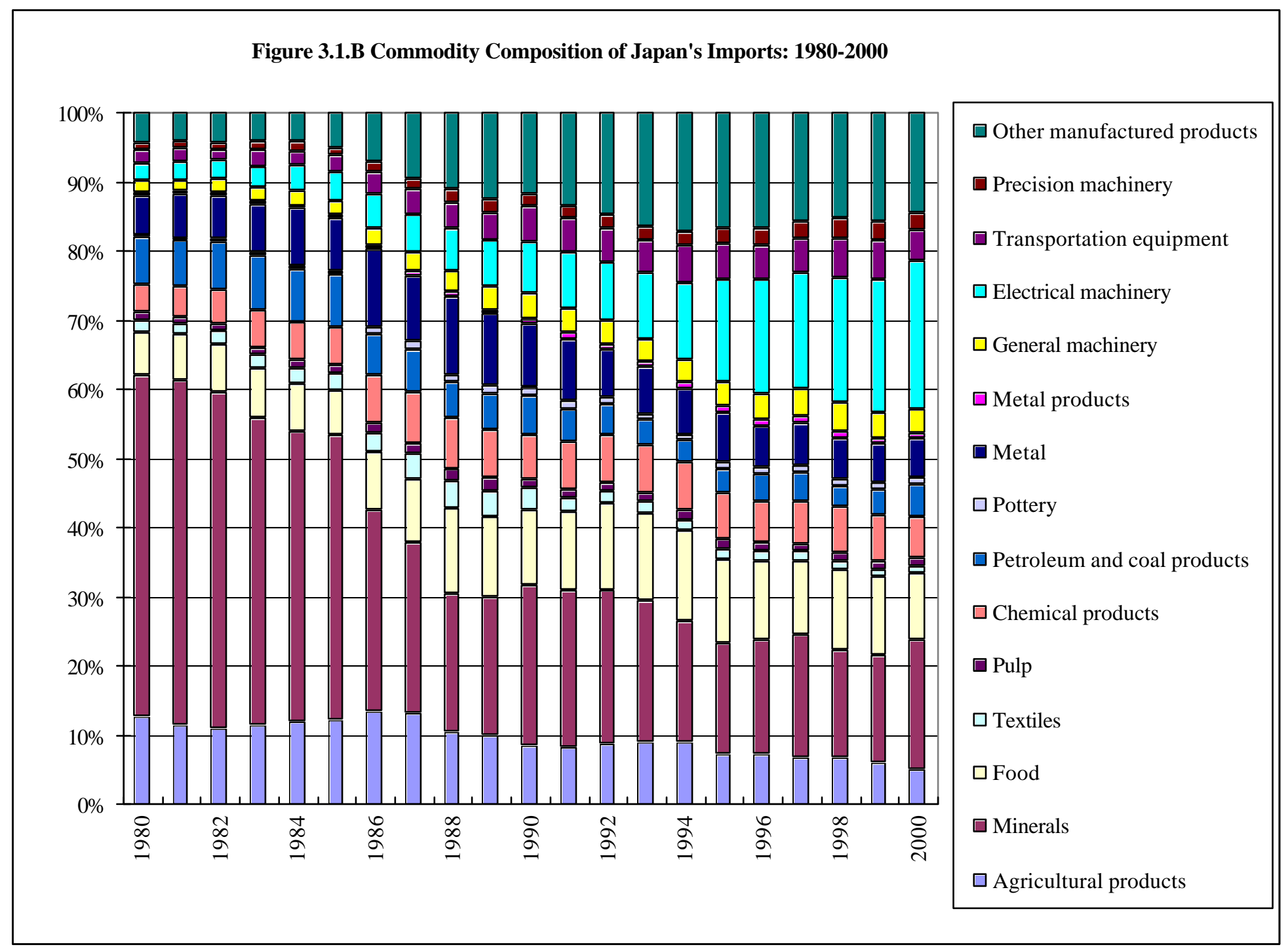

Sources: Economic and Social Research Institute, Cabinet Office, Government of Japan, Annual Report on National Accounts 2002 ,

Economic Planning Agency, Government of Japan, Annual Report on National Accounts 2000 . 
Figure 3.2 Share of Nine East Asian Economies in Japan's Trade in Manufacturing Products: 1980-2000, by Commodity

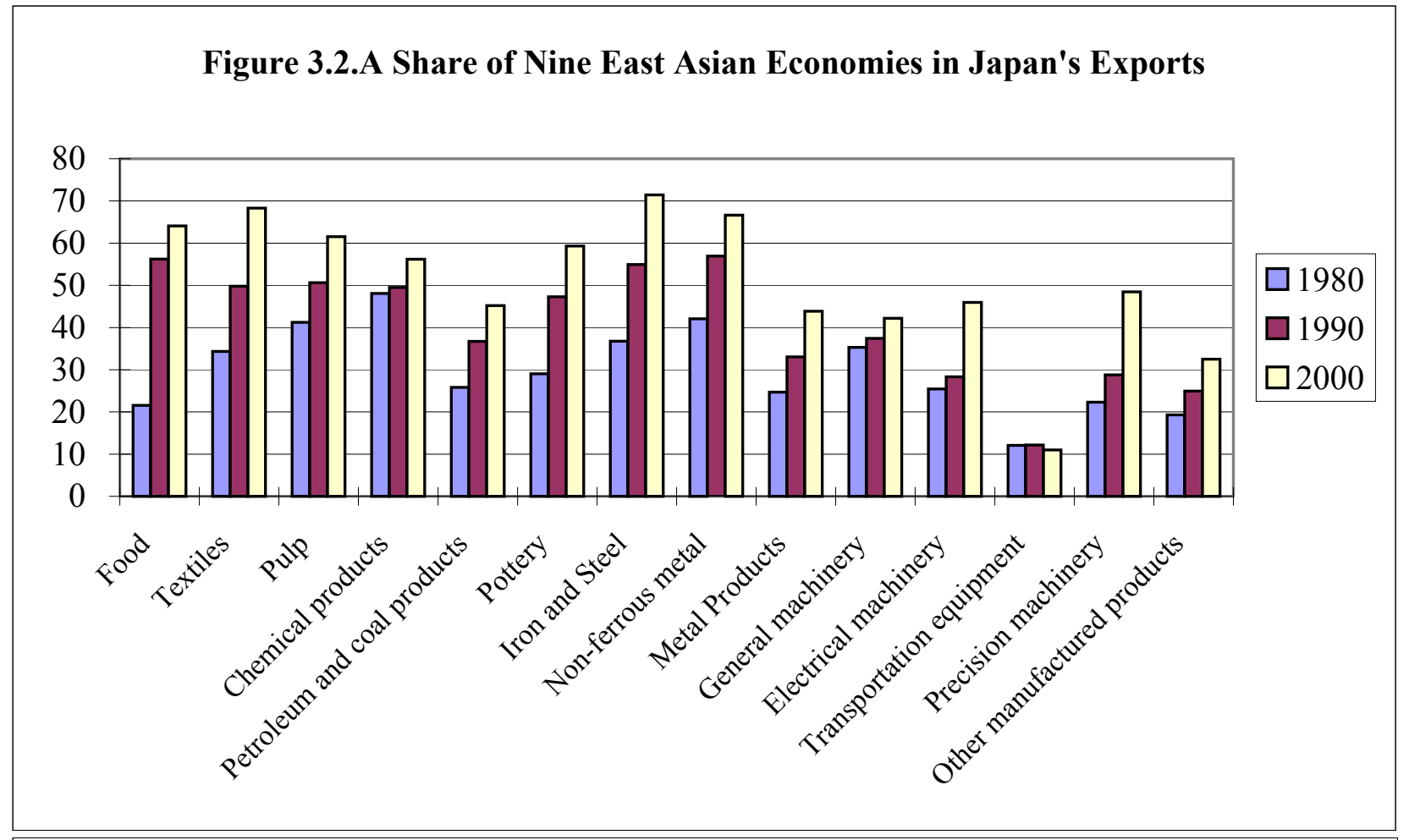

Figure 3.2.B Share of Nine East Asian Economies in Japan's Imports

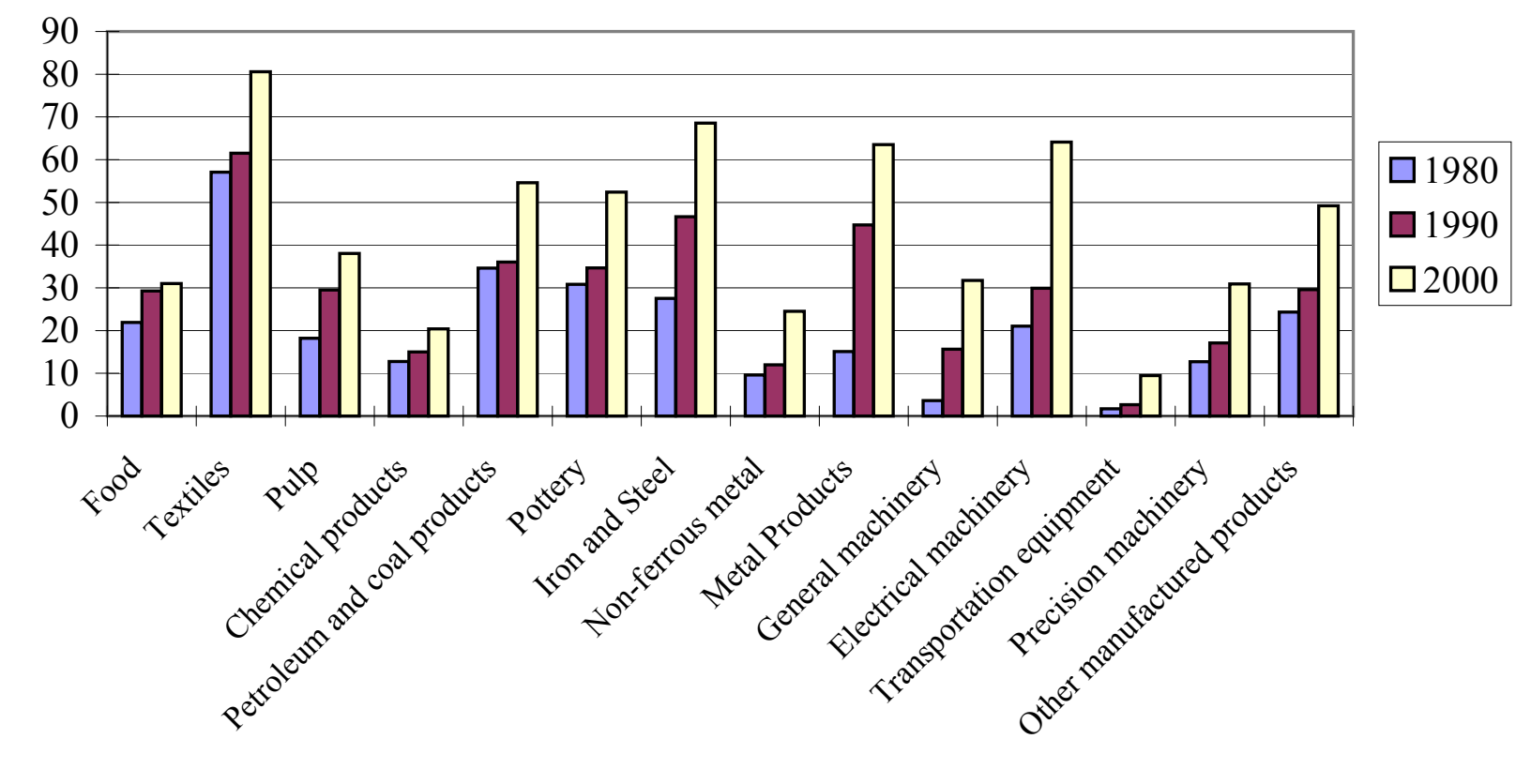

Source: Ministry of Finance, Trade Statistics 
Figure 3.3 Japan's Major Trade Partners: Manufacturing Products, 1980-2000

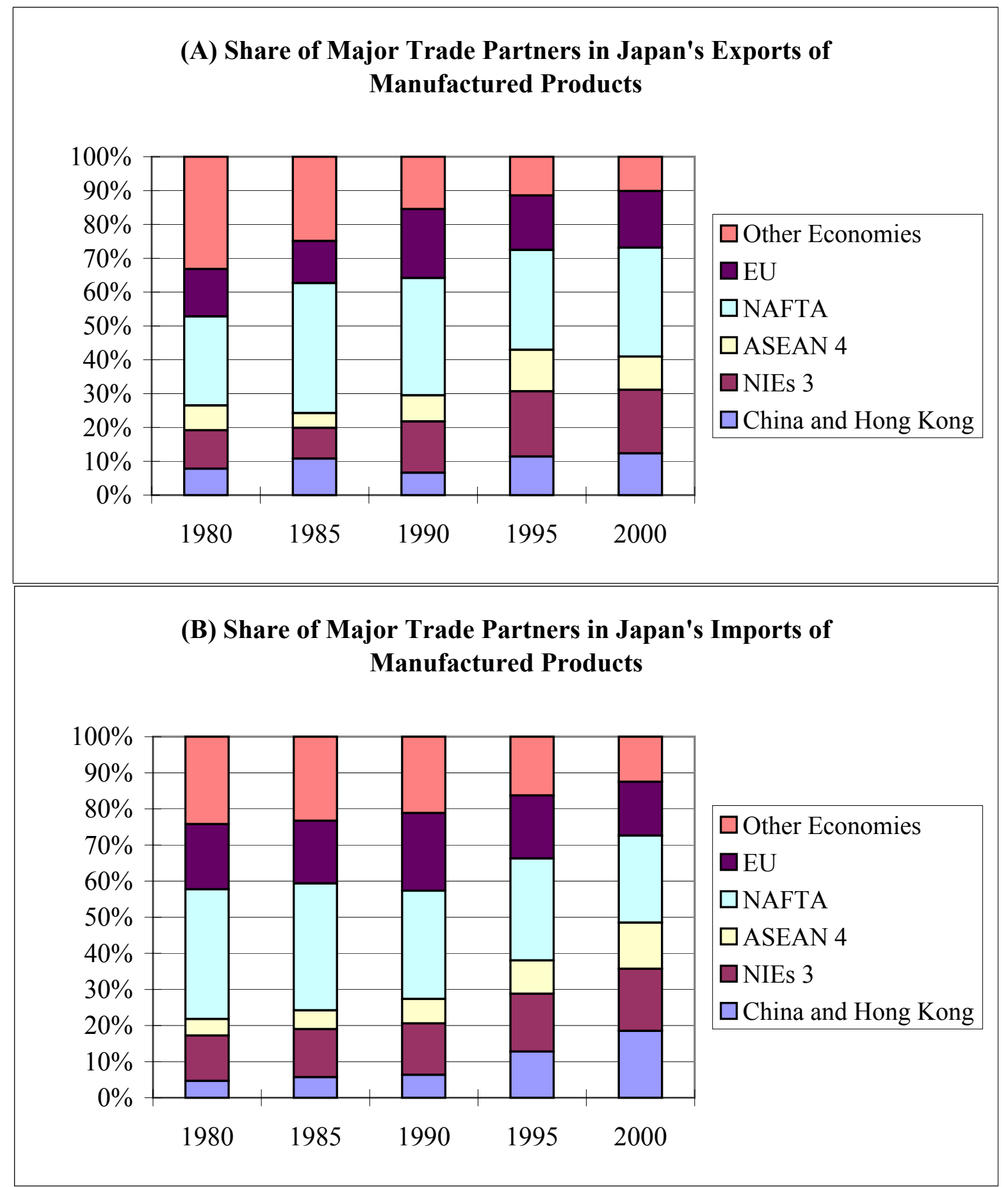

Source: Ministry of Finance, Trade Statistics 
Table 3.2 Japan's Trade in Electrical Machinery and Office Machines with China and Hong Kong in 1999

(billion yen)

\begin{tabular}{|c|c|c|c|}
\hline Commodity classification, SITC R3 & $\begin{array}{c}\text { Japan's exports to } \\
\text { China and Hong } \\
\text { Kong (f.o.b. } \\
\text { base) }\end{array}$ & $\begin{array}{l}\text { Japan's imports } \\
\text { from China and } \\
\text { Hong Kong } \\
\text { (f.o.b. base) }\end{array}$ & $\begin{array}{l}\text { Japan's net- } \\
\text { exports to China } \\
\text { and Hong Kong }\end{array}$ \\
\hline $\begin{array}{l}\text { 75-Office machines \& automatic data processing machines } \\
\text { 751-Office machines } \\
\text { 752-Automatic data processing machines \& units } \\
\text { 759-Parts of and accessories suitable for 751-752 } \\
\text { 76-Telecommunications \& sound recording apparatus } \\
\text { 761-Television receivers } \\
\text { 762-Radio-broadcast receivers } \\
\text { 763-Gramophones, dictating, sound recorders etc } \\
\text { 764-Telecommunications equipment and parts } \\
\text { 77-Electrical machinery, apparatus \& appliance } \\
\text { 771-Electric power machinery and parts thereof } \\
\text { 772-Elect.app.such as switches, relays, fuses, pl } \\
\text { 773-Equipment for distributing electricity } \\
\text { 774-Electric apparatus for medical purposes } \\
\text { 775-Household type, elect.\& non-electrical equipment } \\
\text { 776-Thermionic, cold \& photo-cathode valves, tubes } \\
\text { 778-Electrical machinery and apparatus, n.e.s. }\end{array}$ & \begin{tabular}{r|}
275.3 \\
173.5 \\
59.0 \\
42.8 \\
316.7 \\
37.5 \\
6.8 \\
n.a. \\
272.4 \\
1377.9 \\
65.7 \\
235.2 \\
48.7 \\
12.9 \\
14.1 \\
724.0 \\
277.3 \\
\end{tabular} & $\begin{array}{r}231.0 \\
117.2 \\
83.7 \\
30.1 \\
302.5 \\
39.5 \\
41.2 \\
\text { n.a. } \\
221.8 \\
454.2 \\
122.7 \\
65.9 \\
63.9 \\
1.2 \\
52.3 \\
85.7 \\
62.6 \\
\end{array}$ & $\begin{array}{r}44.2 \\
56.3 \\
-24.8 \\
12.7 \\
14.1 \\
-2.1 \\
-34.4 \\
\text { n.a. } \\
50.6 \\
923.7 \\
-57.0 \\
169.4 \\
-15.2 \\
11.7 \\
-38.3 \\
638.3 \\
214.8 \\
\end{array}$ \\
\hline Total & 1969.8 & 987.7 & 982.1 \\
\hline
\end{tabular}

Source: Statistics Canada, World Trade Analyzer 2001. 
Table 3.3 Factor Contents (Direct plus Indirect) of Trade for Japan's Manufacturing Sector: 1980-2000, by Region

\begin{tabular}{|c|c|c|c|c|c|c|c|c|c|}
\hline \multirow[t]{2}{*}{ Production labor } & \multicolumn{3}{|c|}{ Gross exports } & \multicolumn{3}{|c|}{ Gross imports } & \multicolumn{3}{|c|}{ Net exports } \\
\hline & 1980 & 1990 & 2000 & 1980 & 1990 & 2000 & 1980 & 1990 & 2000 \\
\hline World total & 923,474 & $1,388,633$ & $1,941,421$ & 306,751 & 761,507 & $1,578,368$ & 616,723 & 627,125 & 363,053 \\
\hline China and Hong Kong & 73,317 & 97,278 & 242,423 & 22,976 & 87,209 & 513,402 & 50,341 & 10,070 & $-270,979$ \\
\hline NIEs 3 & 99,132 & 198,831 & 353,213 & 54,302 & 138,387 & 218,617 & 44,830 & 60,444 & 134,596 \\
\hline ASEAN 4 & 61,937 & 103,502 & 189,007 & 10,060 & 51,945 & 177,053 & 51,877 & 51,557 & 11,953 \\
\hline US & 223,380 & 440,972 & 583,364 & 90,578 & 178,069 & 273,127 & 132,801 & 262,903 & 310,237 \\
\hline EU & 133,426 & 286,382 & 324,457 & 61,872 & 174,314 & 208,738 & 71,554 & 112,068 & 115,719 \\
\hline Other economies & 332,281 & 261,667 & 248,957 & 66,963 & 131,583 & 187,430 & 265,318 & 130,084 & 61,527 \\
\hline \multirow[t]{2}{*}{ Non-production labor } & \multicolumn{3}{|c|}{ Gross exports } & \multicolumn{3}{|c|}{ Gross imports } & \multicolumn{3}{|c|}{ Net exports } \\
\hline & 1980 & 1990 & 2000 & 1980 & 1990 & 2000 & 1980 & 1990 & 2000 \\
\hline World total & 408,313 & 675,630 & 985,796 & 118,829 & 291,902 & 607,572 & 289,484 & 383,728 & 378,224 \\
\hline China and Hong Kong & 31,756 & 44,161 & 119,781 & 5,861 & 21,364 & 127,705 & 25,895 & 22,797 & $-7,924$ \\
\hline NIEs 3 & 46,089 & 100,185 & 186,061 & 15,805 & 44,569 & 106,804 & 30,285 & 55,617 & 79,257 \\
\hline ASEAN 4 & 28,616 & 50,583 & 96,495 & 3,679 & 16,693 & 79,591 & 24,937 & 33,890 & 16,904 \\
\hline US & 96,813 & 215,813 & 294,537 & & 87,408 & 136,926 & 54,537 & 128,405 & 157,610 \\
\hline EU & 60,203 & 141,939 & 169,484 & 26,359 & 70,748 & 90,007 & 33,844 & 71,191 & 79,477 \\
\hline Other economies & 144,836 & 122,948 & 119,439 & 24,850 & 51,119 & 66,540 & 119,986 & 71,829 & 52,900 \\
\hline Land (million yen, in 1990 & \multicolumn{3}{|c|}{ Gross exports } & \multicolumn{3}{|c|}{ Gross imports } & \multicolumn{3}{|c|}{ Net exports } \\
\hline prices) & 1980 & 1990 & 2000 & 1980 & 1990 & 2000 & 1980 & 1990 & 2000 \\
\hline World total & $2,367,285$ & $3,154,935$ & $4,251,546$ & 782,374 & $1,777,449$ & $2,895,281$ & $1,584,911$ & $1,377,486$ & $1,356,265$ \\
\hline China and Hong Kong & 202,601 & 223,700 & 557,028 & 39,703 & 128,046 & 621,391 & 162,899 & 95,654 & $-64,362$ \\
\hline NIEs 3 & 282,507 & 502,354 & 807,407 & 107,479 & 275,660 & 437,886 & 175,028 & 226,694 & 369,521 \\
\hline ASEAN 4 & 183,807 & 271,144 & 428,155 & 34,754 & 124,603 & 337,695 & 149,052 & 146,541 & 90,460 \\
\hline US & 522,355 & 931,945 & $1,195,965$ & 228,689 & 418,488 & 565,778 & 293,666 & 513,457 & 630,186 \\
\hline EU & 297,871 & 591,223 & 655,089 & 149,588 & 397,799 & 457,527 & 148,284 & 193,424 & 197,562 \\
\hline Other economies & 878,144 & 634,570 & 607,902 & 222,161 & 432,854 & 475,004 & 655,982 & 201,716 & 132,898 \\
\hline \multirow{2}{*}{$\begin{array}{l}\text { Capital stock (million yen, } \\
\text { in } 1990 \text { prices) }\end{array}$} & \multicolumn{3}{|c|}{ Gross exports } & \multicolumn{3}{|c|}{ Gross imports } & \multicolumn{3}{|c|}{ Net exports } \\
\hline & 1980 & 1990 & 2000 & 1980 & 1990 & 2000 & 1980 & 1990 & 2000 \\
\hline World total & $11,087,602$ & $15,378,504$ & $21,701,611$ & $3,068,328$ & $7,169,480$ & $12,586,585$ & $8,019,274$ & $8,209,024$ & $9,115,026$ \\
\hline China and Hong Kong & 944,937 & $1,111,021$ & $2,901,756$ & 145,135 & 469,155 & $2,313,326$ & 799,802 & 641,866 & 588,430 \\
\hline NIEs 3 & $1,327,911$ & $2,442,986$ & $4,195,098$ & 403,842 & $1,113,916$ & $2,263,765$ & 924,069 & $1,329,070$ & $1,931,333$ \\
\hline ASEAN 4 & 878,622 & $1,312,625$ & $2,286,969$ & 114,037 & 401,754 & $1,552,102$ & 764,585 & 910,871 & 734,867 \\
\hline US & $2,479,216$ & $4,629,732$ & $6,052,100$ & 975,571 & $1,879,475$ & $2,710,964$ & $1,503,645$ & $2,750,257$ & $3,341,137$ \\
\hline EU & $1,372,409$ & $2,903,521$ & $3,353,937$ & 629,500 & $1,691,120$ & $2,012,755$ & 742,909 & $1,212,401$ & $1,341,182$ \\
\hline Other economies & $4,084,507$ & $2,978,619$ & $2,911,750$ & 800,244 & $1,614,061$ & $1,733,673$ & $3,284,263$ & $1,364,559$ & $1,178,077$ \\
\hline
\end{tabular}


Table 3.4 Changes in Factor Contents (Direct plus Indirect) of Net Exports for Japan's Manufacturing Sector: 1980-2000, by Region Production labor

\begin{tabular}{lrrrrrr}
\hline \hline & \multicolumn{7}{c}{ Net exports } \\
& \multicolumn{2}{c}{$1980-90$} & \multicolumn{2}{c}{$1990-2000$} & \multicolumn{2}{c}{$1980-2000$} \\
\hline World total & 10,403 & $(0.1 \%)$ & $-264,073$ & $(-3.4 \%)$ & $-253,670$ & $(-3.3 \%)$ \\
China and Hong Kong & $-40,272$ & $(-0.5 \%)$ & $-281,049$ & $(-3.6 \%)$ & $-321,321$ & $(-4.2 \%)$ \\
NIEs 3 & 15,614 & $(0.2 \%)$ & 74,152 & $(1.0 \%)$ & 89,766 & $(1.2 \%)$ \\
ASEAN & -320 & $(-0.0 \%)$ & $-39,603$ & $(-0.5 \%)$ & $-39,924$ & $(-0.5 \%)$ \\
US & 130,101 & $(1.7 \%)$ & 47,335 & $(0.6 \%)$ & 177,436 & $(2.3 \%)$ \\
EU & 40,513 & $(0.5 \%)$ & 3,651 & $(0.0 \%)$ & 44,164 & $(0.6 \%)$ \\
Other economies & $-135,234$ & $(-1.8 \%)$ & $-68,557$ & $(-0.9 \%)$ & $-203,792$ & $(-2.6 \%)$ \\
\hline \hline
\end{tabular}

Non-production labor

\begin{tabular}{lrrrrrr}
\hline & \multicolumn{7}{c}{ Net exports } \\
& \multicolumn{2}{c}{$1980-90$} & \multicolumn{2}{c}{$1990-2000$} & \multicolumn{2}{c}{$1980-2000$} \\
\hline World total & 94,244 & $(2.7 \%)$ & $-5,505$ & $(-0.2 \%)$ & 88,739 & $(2.6 \%)$ \\
China and Hong Kong & $-3,098$ & $(-0.1 \%)$ & $-30,721$ & $(-0.9 \%)$ & $-33,819$ & $(-1.0 \%)$ \\
NIEs 3 & 25,332 & $(0.7 \%)$ & 23,641 & $(0.7 \%)$ & 48,973 & $(1.4 \%)$ \\
ASEAN 4 & 8,953 & $(0.3 \%)$ & $-16,986$ & $(-0.5 \%)$ & $-8,033$ & $(-0.2 \%)$ \\
US & 73,868 & $(2.1 \%)$ & 29,205 & $(0.8 \%)$ & 103,073 & $(3.0 \%)$ \\
EU & 37,347 & $(1.1 \%)$ & 8,286 & $(0.2 \%)$ & 45,632 & $(1.3 \%)$ \\
Other economies & $-48,157$ & $(-1.4 \%)$ & $-18,929$ & $(-0.5 \%)$ & $-67,087$ & $(-1.9 \%)$ \\
\hline \hline
\end{tabular}

Land (million yen, in 1990 prices)

\begin{tabular}{lrrrrrr}
\hline \hline & \multicolumn{7}{c}{ Net exports } \\
& \multicolumn{2}{c}{$1980-90$} & \multicolumn{2}{c}{$1990-2000$} & \multicolumn{2}{c}{$1980-2000$} \\
\hline World total & $-207,425$ & $(-1.6 \%)$ & $-21,221$ & $(-0.2 \%)$ & $-228,646$ & $(-1.8 \%)$ \\
China and Hong Kong & $-67,244$ & $(-0.5 \%)$ & $-160,017$ & $(-1.2 \%)$ & $-227,261$ & $(-1.8 \%)$ \\
NIEs 3 & 51,666 & $(0.4 \%)$ & 142,826 & $(1.1 \%)$ & 194,492 & $(1.5 \%)$ \\
ASEAN 4 & $-2,512$ & $(-0.0 \%)$ & $-56,080$ & $(-0.4 \%)$ & $-58,592$ & $(-0.5 \%)$ \\
US & 219,791 & $(1.7 \%)$ & 116,729 & $(0.9 \%)$ & 336,521 & $(2.6 \%)$ \\
EU & 45,140 & $(0.3 \%)$ & 4,138 & $(0.0 \%)$ & 49,278 & $(0.4 \%)$ \\
Other economies & $-454,267$ & $(-3.5 \%)$ & $-68,818$ & $(-0.5 \%)$ & $-523,085$ & $(-4.1 \%)$ \\
\hline \hline
\end{tabular}

Capital stock (million yen, in 1990 prices)

\begin{tabular}{lrrrrrr}
\hline \hline & \multicolumn{7}{c}{ Net exports } \\
& \multicolumn{2}{c}{$1980-90$} & \multicolumn{2}{c}{$1990-2000$} & \multicolumn{2}{c}{$1980-2000$} \\
\hline World total & 189,751 & $(0.3 \%)$ & 906,001 & $(1.6 \%)$ & $1,095,752$ & $(2.0 \%)$ \\
China and Hong Kong & $-157,936$ & $(-0.3 \%)$ & $-53,436$ & $(-0.1 \%)$ & $-211,372$ & $(-0.4 \%)$ \\
NIEs 3 & 405,001 & $(0.7 \%)$ & 602,262 & $(1.1 \%)$ & $1,007,263$ & $(1.8 \%)$ \\
ASEAN 4 & 146,286 & $(0.3 \%)$ & $-176,004$ & $(-0.3 \%)$ & $-29,718$ & $(-0.1 \%)$ \\
US & $1,246,611$ & $(2.2 \%)$ & 590,880 & $(1.1 \%)$ & $1,837,492$ & $(3.3 \%)$ \\
EU & 469,492 & $(0.8 \%)$ & 128,781 & $(0.2 \%)$ & 598,273 & $(1.1 \%)$ \\
Other economies & $-1,919,705$ & $(-3.5 \%)$ & $-186,482$ & $(-0.3 \%)$ & $-2,106,186$ & $(-3.8 \%)$ \\
\hline \hline
\end{tabular}

Notes: Data in parentheses denote the ratio of factor contents to total input in Japan's manufacturing sector in 1990. The data on total input are taken from the Ministry of International Trade and Industry, Census of Manufactures 1990. 
Table 3.5 Physical and Human Capital Deepening in the Japanese Manufacturing Sector

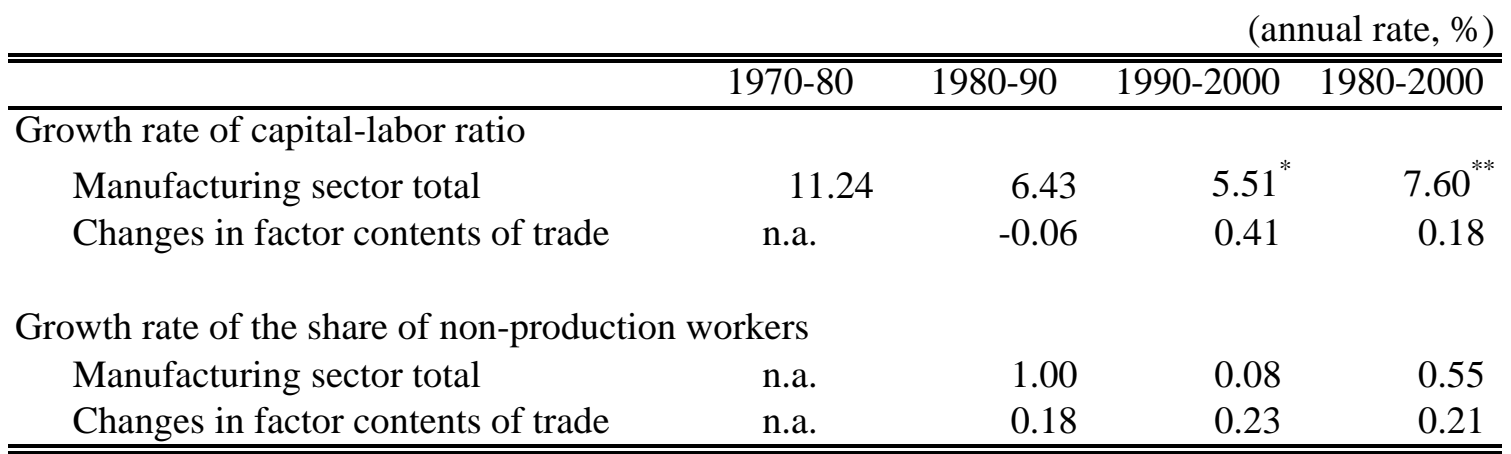

"The growth rate of the capital-labor ratio denotes the average annual growth rate from 1990 to 1998.

${ }^{* *}$ The growth rate of the capital-labor ratio denotes the average annual growth rate from 1980 to 1998.

Source: Authors' calculation based on the results of Tables 2.1, 2.2, and 3.4. 


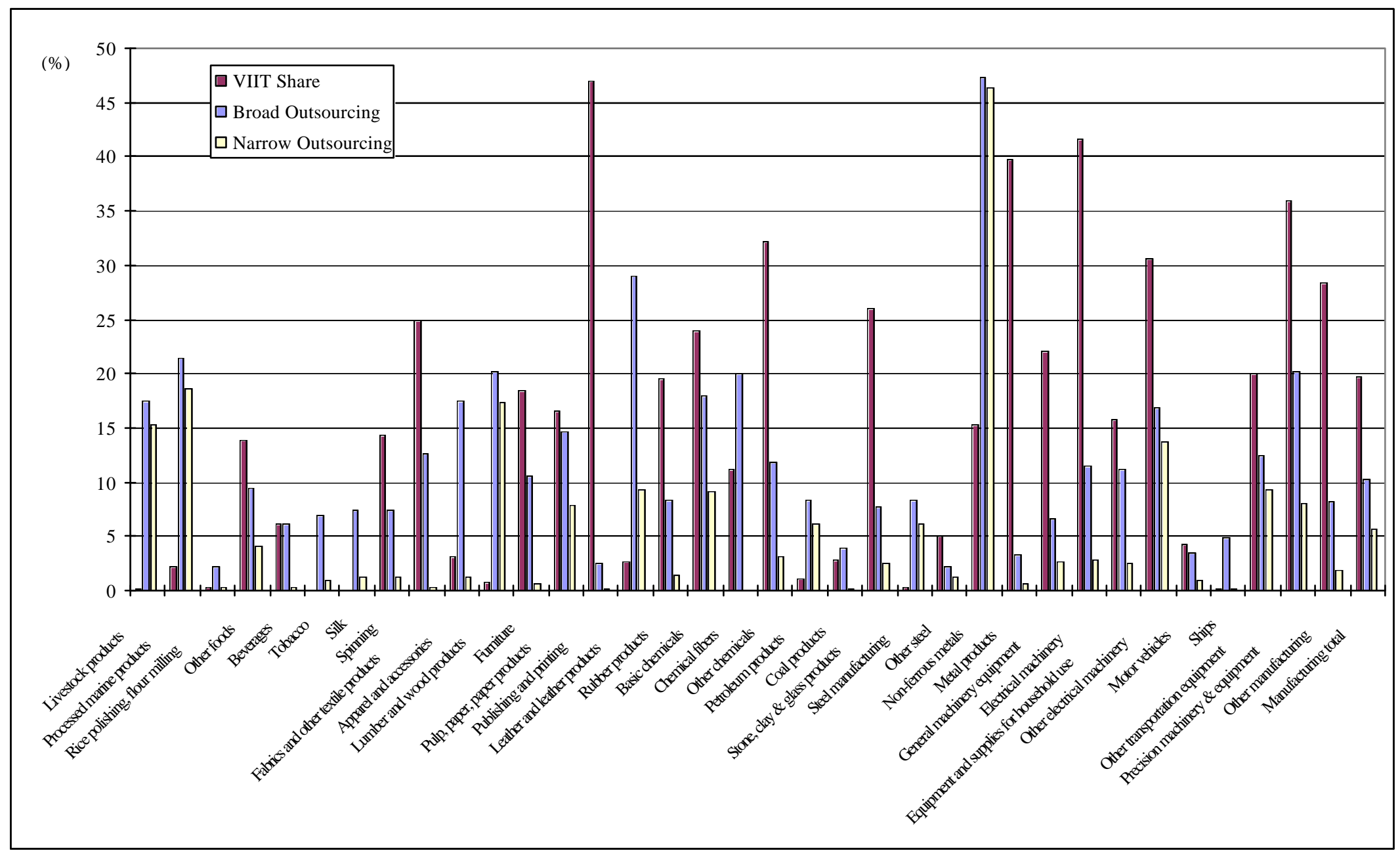

Figure 4.1 Vertical Intra-Industry Trade Share and Outsourcing Share by Industry: 2000

Source: Authors' calculation. 


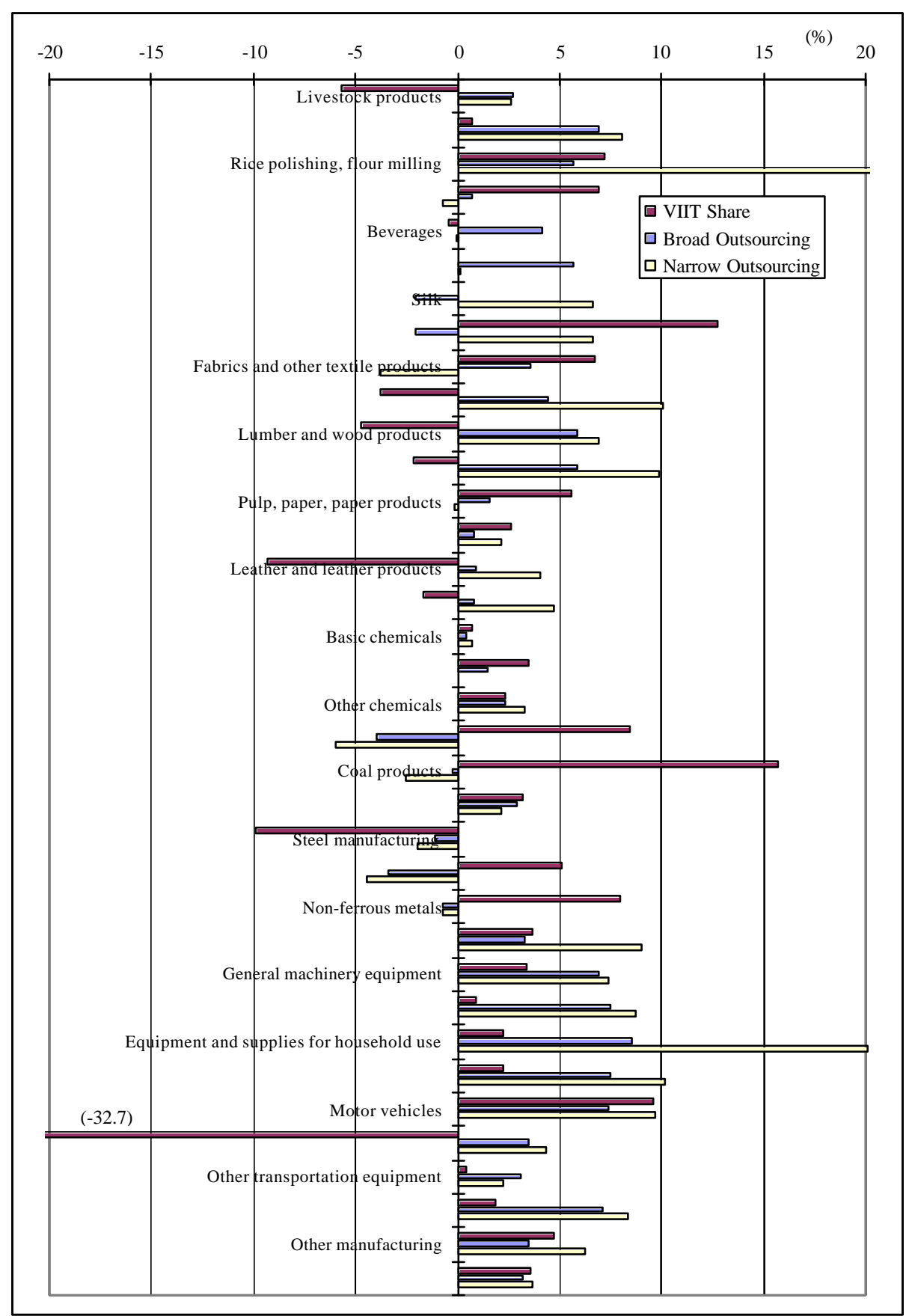

Growth rate of VIIT share: ? $\ln ($ VIIT/Total trade)

Growth rate of broad outsourcing share: ? In (Broad outsourcing/Total intermediate inputs)

Growth rate of narrow outsourcing share: ? ln (Narrow outsourcing/Total intermediate inputs)

Figure 4.2 Annual Growth Rate of Vertical Intra-Industry Trade Share and Outsourcing Share by Industry: 1988-2000 
Table 4.1 Correlation Coefficient Matrix

\begin{tabular}{|c|c|c|c|c|c|c|}
\hline & (a) & (b) & (c) & (d) & (e) & (f) \\
\hline & $\begin{array}{l}\text { Capital-Labor } \\
\text { Ratio }\end{array}$ & $\begin{array}{l}\text { Skilled Worker } \\
\text { Share }\end{array}$ & $\begin{array}{l}\text { Non-production } \\
\text { Worker Share }\end{array}$ & VIIT Share & $\begin{array}{c}\text { Broad } \\
\text { Outsourcing }\end{array}$ & $\begin{array}{c}\text { Narrow } \\
\text { Outsourcing }\end{array}$ \\
\hline (a) & 1 & & & & & \\
\hline (b) & $0.435 * * *$ & 1 & & & & \\
\hline (c) & $0.471 * * *$ & $0.592 * * *$ & 1 & & & \\
\hline (d) & -0.059 & 0.262 & -0.050 & 1 & & \\
\hline (e) & -0.017 & $0.292 *$ & 0.210 & -0.147 & 1 & \\
\hline (f) & 0.146 & $0.299 *$ & 0.203 & 0.009 & $0.554 * * *$ & 1 \\
\hline
\end{tabular}

Note: Each variable denotes the average annual growth rate for the period from 1988 to 2000 . $*$ significant at $10 \%$ level, $* * *$ significant at $1 \%$ level.

Source: Authors' calculation. 


\section{Table 4.2 GLS Estimation Results}

Dependent variable:

Skilled workers' share in total number of workers (SKILLED)

Non-production workers' share in total number of workers (NONPROD)

Capital-labor ratio (KL)

\begin{tabular}{|c|c|c|c|c|c|c|c|c|}
\hline \multirow[b]{2}{*}{$\ln ($ IThard/VA) } & \multicolumn{2}{|c|}{$\begin{array}{c}\text { SKILLED } \\
(1) \\
\end{array}$} & \multicolumn{2}{|c|}{$\begin{array}{c}\text { SKILLED } \\
(2) \\
\end{array}$} & \multicolumn{2}{|c|}{$\begin{array}{c}\text { NONPROD } \\
(3) \\
\end{array}$} & \multicolumn{2}{|c|}{$\begin{array}{c}\text { NONPROD } \\
(4) \\
\end{array}$} \\
\hline & $\begin{array}{r}1.4988 \\
(7.30)\end{array}$ & $* * *$ & $\begin{array}{r}1.3981 \\
(7.07)\end{array}$ & $* * *$ & $\begin{array}{r}1.7536 \\
(5.49)\end{array}$ & $* * *$ & $\begin{array}{r}2.0452 \\
(6.32)\end{array}$ & $* * *$ \\
\hline $\ln ($ ITsoft/VA) & $\begin{array}{r}0.0364 \\
(0.43)\end{array}$ & & $\begin{array}{r}0.0348 \\
(0.45)\end{array}$ & & $\begin{array}{r}-0.0509 \\
(-0.46)\end{array}$ & & $\begin{array}{r}-0.0401 \\
(-0.33)\end{array}$ & \\
\hline $\ln ($ NonIT/VA) & $\begin{array}{r}-0.7162 \\
(-2.58)\end{array}$ & $* *$ & $\begin{array}{r}-0.5542 \\
(-2.02)\end{array}$ & $* *$ & $\begin{array}{r}-0.5864 \\
(-1.26)\end{array}$ & & $\begin{array}{r}-0.9365 \\
(-2.02)\end{array}$ & $* *$ \\
\hline $\ln \mathrm{VA}$ & $\begin{array}{r}1.0596 \\
(7.20)\end{array}$ & $* * *$ & $\begin{array}{r}1.0844 \\
(6.92)\end{array}$ & $* * *$ & $\begin{array}{r}1.4477 \\
(5.17)\end{array}$ & $* * *$ & $\begin{array}{r}1.4978 \\
(6.04)\end{array}$ & $* * *$ \\
\hline RDexp/VA & $\begin{array}{r}3.0787 \\
(2.18)\end{array}$ & $* *$ & $\begin{array}{r}2.4287 \\
(1.85)\end{array}$ & $*$ & $\begin{array}{r}3.8564 \\
(1.79)\end{array}$ & & $\begin{array}{r}5.5175 \\
(2.38)\end{array}$ & $* *$ \\
\hline \multicolumn{9}{|l|}{ ln (wage/rental price) } \\
\hline VIITworld/Shipment & $\begin{array}{c}0.1521 \\
(3.68)\end{array}$ & $* * *$ & & & $\begin{array}{r}0.0351 \\
(0.84)\end{array}$ & & & \\
\hline VIITasia9/Shipment & & & $\begin{array}{r}0.2241 \\
(3.10)\end{array}$ & $* * *$ & & & $\begin{array}{r}0.0370 \\
(0.24)\end{array}$ & \\
\hline VIITnon-asia/Shipment & & & $\begin{array}{r}0.0009 \\
(1.78)\end{array}$ & & & & $\begin{array}{r}0.0005 \\
(0.92)\end{array}$ & \\
\hline outsourcing (narrow) & $\begin{array}{r}0.0061 \\
(0.73)\end{array}$ & & $\begin{array}{r}0.0033 \\
(0.44)\end{array}$ & & $\begin{array}{r}0.0075 \\
(0.68)\end{array}$ & & $\begin{array}{r}0.0099 \\
(0.83)\end{array}$ & \\
\hline outsourcing (difference) & $\begin{array}{r}-0.0320 \\
(-1.14)\end{array}$ & & $\begin{array}{r}-0.0189 \\
(-0.72)\end{array}$ & & $\begin{array}{r}-0.0315 \\
(-0.70)\end{array}$ & & $\begin{array}{r}-0.0718 \\
(-1.45)\end{array}$ & \\
\hline _cons & $\begin{array}{r}-1.6644 \\
(-0.67)\end{array}$ & & $\begin{array}{r}-2.4111 \\
(-0.94)\end{array}$ & & $\begin{array}{r}14.4863 \\
(3.22)\end{array}$ & $* * *$ & $\begin{array}{r}14.8355 \\
(3.61)\end{array}$ & $* * *$ \\
\hline $\mathrm{N}$ & 439 & & 439 & & 439 & & 439 & \\
\hline Wald & 325.60 & $* * *$ & 271.41 & $* * *$ & 187.69 & $* * *$ & 221.39 & $* * *$ \\
\hline
\end{tabular}

Note: 1) Presence of AR(1) autocorrelation within panels and heteroskedasticity across panels is assumed.

2) The numbers in parentheses are z-statistics.

3) All equations include year dummies which are suppressed here. The estimation period for equations (1 2000, and the estimation period for equation (5) is 1988-1998.

*significant at $10 \%$ level, ** significant at $5 \%$ level, ***significant at $1 \%$ level (two-tailed test). Source: Authors' calculations. 


\section{Appendix Table 1. Occupational Classification in the Population Census}

Major Groups

1 Professional and Technical Occupations

2 Managers and Administrators

3 Clerical and Secretarial Occupations

4 Sales Occupations

5 Services Occupations

6 Protective Service Occupations

7 Occupations in Agriculture, Forestry and Fishing

8 Occupations in Transportation and Telecommunication

9 Plant and Machine Occupations, Craft and Related Occupations, and Occupations in Mining and Construction

10 Other Occupations

Skilled workers: Groups 1 and 2

Production workers: Group 9 
Appendix Table 3. Correspondence Table: Fukao-Ito Classification correspondence to 1980-85-90 Japan Linked InputOutput Standard Classification (manufacturing)

\begin{tabular}{|c|c|c|c|}
\hline Fukao-Ito Classification & Linked I-O & Fukao-Ito Classification & Linked I-O \\
\hline 57 Beef meat (bone meat), Pork (born meat), I & $1111-010$ & 112 Woven fabric apparel, Knitted apparel & $1521-011$ \\
\hline 58 By-products of slaughtering and meat proces & 1111-015 & 113 Other wearing apparel and clothing accessor: & $1522-011$ \\
\hline 59 Processed meat products & $1112-011$ & 114 Carpets and floor mats, Bedding, Other read & $1529-090$ \\
\hline 60 Bottled or canned meat products & $1112-021$ & 115 Timber & $1611-011$ \\
\hline 61 Animal oils and fats & $1112-031$ & 116 Plywood & $1611-021$ \\
\hline 62 Drinking milk & $1112-041$ & 117 Wooden chips & $1611-031$ \\
\hline 63 Dairy products & $1112-042$ & 118 Wooden products for construction & 1619-091 \\
\hline 64 Frozen fish and shellfish & $1113-011$ & 119 Other wooden products, n.e.c. & 1619-099 \\
\hline 65 Salted, dried or smoked seafood & $1113-021$ & 120 Wooden furniture and fixtures, Wooden fixt & $1711-010$ \\
\hline 66 Bottled or canned seafood & $1113-031$ & 121 Metallic furniture and fixtures & $1711-031$ \\
\hline 67 Fish paste & $1113-041$ & 122 Pulp, Waste paper & $1811-011$ \\
\hline 68 Fish oil and meal & $1113-051$ & 123 Foreign paper and Japanese paper & $1812-011$ \\
\hline 69 Other processed seafoods & $1113-099$ & 124 Paperboard & 1813-011 \\
\hline 70 Milled rice & $1114-011$ & 125 Corrugated cardboard & $1813-021$ \\
\hline 71 Other grain milling & $1114-019$ & 126 Coated paper and building (construction) pal & $1813-022$ \\
\hline 72 Wheat flour & $1114-021$ & 127 Corrugated card board boxes, Other paper cc & $1821-010$ \\
\hline 73 Other grain milled products & $1114-029$ & 128 Other pulp, paper and processed paper prodı & $1829-090$ \\
\hline 74 Noodles & $1115-011$ & 129 Newspapers & 1911-011 \\
\hline 75 Bread & $1115-021$ & 130 Printing, plate making and bookbinding & 1911-021 \\
\hline 76 Confectionery & $1115-022$ & 131 Publishing & 1911-031 \\
\hline 77 Bottled or canned vegetables and fruits & $1116-011$ & 132 Ammonia & 2011-011 \\
\hline 78 Preserved agricultural foodstuffs (other than & $1116-021$ & 133 Chemical fertilizer & 2011-021 \\
\hline 79 Refined sugar & $1117-011$ & & 2011-029 \\
\hline 80 Other sugar and by-products of sugar & $1117-019$ & 134 Soda ash & $2021-011$ \\
\hline 81 Starch & $1117-021$ & 135 Caustic soda & $2021-012$ \\
\hline 82 Dextrose, syrup and isomerized sugar & $1117-031$ & 136 Liquid chlorine & $2021-013$ \\
\hline 83 Vegetable oils, Cooking oil & $1117-040$ & 137 Other industrial soda chemicals & 2021-019 \\
\hline 84 Vegetable meal & $1117-043$ & 138 Titanium oxide & 2029-021 \\
\hline 85 Crude salt & $1117-051$ & 139 Carbon black & 2029-022 \\
\hline 86 Salt & $1117-052$ & 140 Other inorganic pigments & 2029-029 \\
\hline 87 Condiments and seasonings & $1117-061$ & 141 Compressed gas and liquified gas & 2029-031 \\
\hline 88 Prepared frozen foods & $1119-011$ & 142 Other industrial inorganic chemicals & 2029-099 \\
\hline 89 Retort foods & $1119-021$ & & 2029-011 \\
\hline 90 Dishes, sushi, lunchboxes, School lunch (put & $1119-090$ & 143 Ethylene & 2031-011 \\
\hline 91 Refined sake & $1121-011$ & 144 Propylene & 2031-012 \\
\hline 92 Beer & $1121-021$ & 145 Other petrochemical basic products & 2031-019 \\
\hline 93 Ethyl alcohol for liquor manufacturing & $1121-031$ & 146 Pure benzene & 2031-021 \\
\hline 94 Whiskey and brandy & $1121-041$ & 147 Pure toluene & $2031-022$ \\
\hline 95 Other liquors & 1121-099 & 148 Xylene & $2031-023$ \\
\hline 96 Tea and roasted coffee & $1129-011$ & 149 Other petrochemical aromatic products & $2031-029$ \\
\hline 97 Soft drinks & $1129-021$ & 150 Acetic acid & 2032-011 \\
\hline 98 Manufactured ice & $1129-031$ & 151 Acetic acid vinyl monomer & 2032-012 \\
\hline 99 Feeds & $1131-011$ & 152 Styrene monomer & 2032-013 \\
\hline 100 Organic fertilizers, n.e.c. & $1131-021$ & 153 Synthetic rubber & 2032-014 \\
\hline 101 Tobacco & $1141-011$ & 154 Synthetic alcohol, Ethylene dichloride, Acr! & 2032-019 \\
\hline 102 Raw silk & $1511-011$ & 155 Methane derivatives & 2039-021 \\
\hline \multirow[t]{4}{*}{103 Fiber yarns } & $1511-021$ & 156 Oil and fat industrial chemicals & 2039-031 \\
\hline & $1511-031$ & 157 Plasticizers & 2039-041 \\
\hline & $1511-041$ & 158 Synthetic dyes & 2039-051 \\
\hline & $1511-099$ & 159 Other industrial organic chemicals & 2039-099 \\
\hline 104 Cotton and staple fiber fabrics (inc. fabrics $\mathrm{c}$ & $1512-011$ & & 2039-011 \\
\hline 105 Silk and artificial silk fabrics (inc. fabrics of & $1512-021$ & 160 Thermo-setting resins & 2041-011 \\
\hline \multirow[t]{3}{*}{106 Woolen fabrics, hemp fabrics, and other fab } & $1512-031$ & 161 Thermoplastic resin, Polyethylene (low den & 2041-091 \\
\hline & $1512-091$ & 162 High functionality resins & 2041-092 \\
\hline & $1512-099$ & 163 Other resins & 2041-099 \\
\hline 107 Knitting fabrics & $1513-011$ & 164 Rayon, acetate & 2051-011 \\
\hline 108 Yarn and fabric dyeing and finishing (proces & $1514-011$ & 165 Synthetic fibers & $2051-021$ \\
\hline 109 Rope and nets & $1519-011$ & 166 Medicaments & 2061-011 \\
\hline 110 Fabricated textiles for medical use & $1519-031$ & 167 Soap and synthetic detergents, Surface activ & 2071-010 \\
\hline 111 Other fabricated textile products & $1519-099$ & 168 Cosmetics, toilet preparations and dentifrice & 2071-021 \\
\hline
\end{tabular}




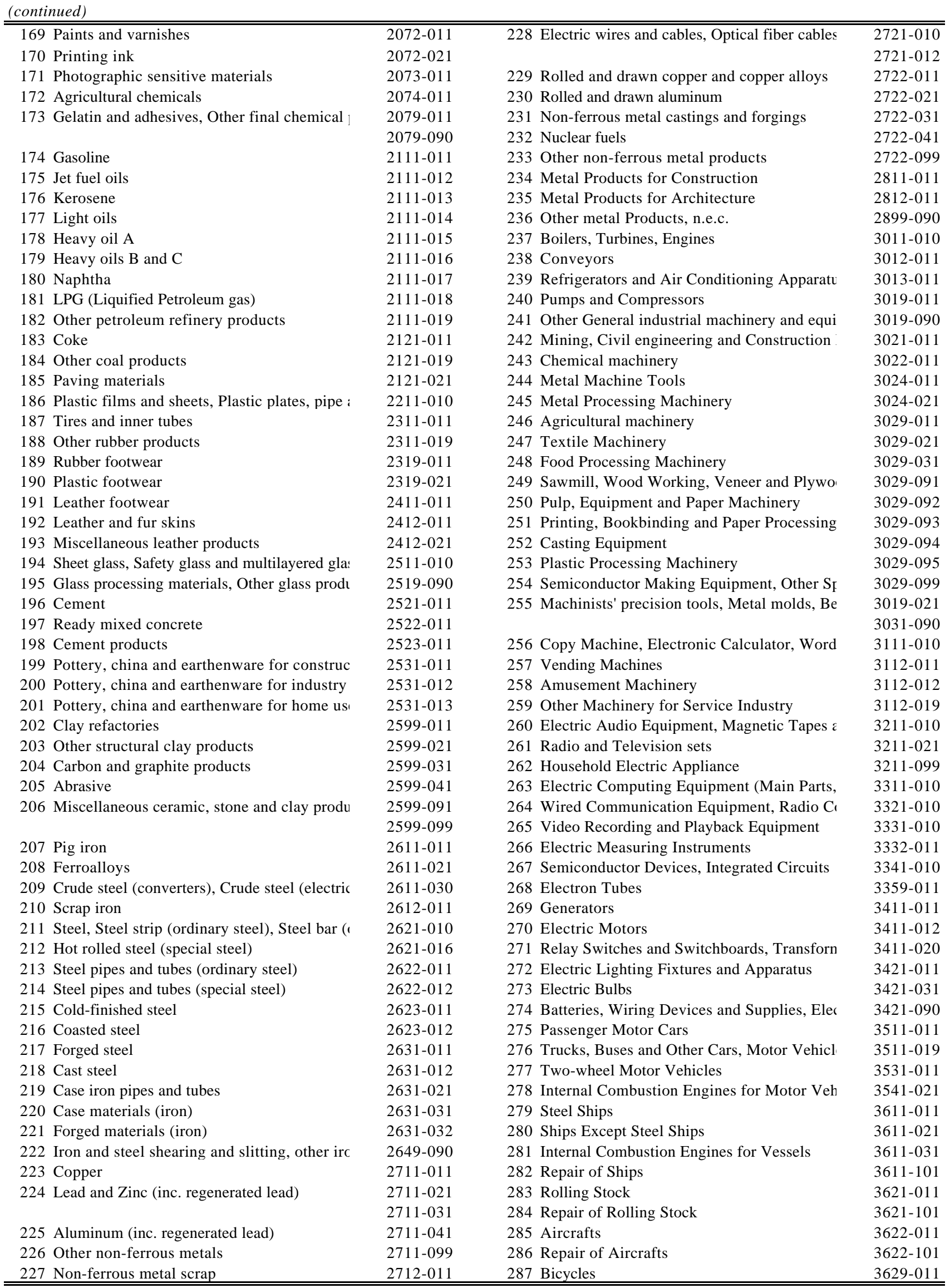




\begin{tabular}{ll}
\hline \hline 288 Transport Equipment for Industrial Use & $3629-091$ \\
289 Other Transport Equipment, n.e.c. & $3629-099$ \\
290 Camera & $3711-011$ \\
291 Other Photographic and Optical Instrument & $3711-099$ \\
292 Watches and Clocks & $3712-011$ \\
293 Professional and Scientific Instruments & $3719-011$ \\
294 Analytical Instruments, Testing Machine, M & $3719-021$ \\
295 Medial Instruments & $3719-031$ \\
296 Toys, Sporting and Athletic Goods & $3911-010$ \\
297 Musical Instruments, Audio and Video Reco & $3919-010$ \\
298 Writing Instruments and Stationery & $3919-031$ \\
299 Small Personal Adornments & $3919-041$ \\
300 "Tatami" (Straw Matting) and Straw Produc & $3919-051$ \\
301 Ordnance & $3919-061$ \\
302 Miscellaneous Manufacturing Products & $3919-099$ \\
\hline \hline
\end{tabular}


Appendix Table 4. Correspondence Table

--- JIP Classification correspondence to Fukao-Ito Classification (manufacturing)---

\begin{tabular}{|c|c|c|c|c|c|c|c|c|}
\hline \multirow{2}{*}{$\begin{array}{l}\text { JIP Industry } \\
11 \text { Livestock products } \\
\end{array}$} & \multicolumn{8}{|c|}{ Fukao-Ito Classification } \\
\hline & 57 & 58 & 59 & 60 & 61 & 62 & 63 & \\
\hline 12 Processed marine products & 64 & 65 & 66 & 67 & 68 & 69 & & \\
\hline 13 Rice polishing, flour milling & 70 & 71 & 72 & 73 & & & & \\
\hline \multirow[t]{2}{*}{14 Other foods } & 74 & 75 & 76 & 77 & 78 & 79 & 80 & 81 \\
\hline & 84 & 85 & 86 & 87 & 88 & 89 & 90 & 99 \\
\hline 15 Beverages & 91 & 92 & 93 & 94 & 95 & 96 & 97 & 98 \\
\hline 16 Tobacco & 101 & & & & & & & \\
\hline 17 Silk & 102 & & & & & & & \\
\hline 18 Spinning & 103 & & & & & & & \\
\hline 19 Fabrics and other textile products & 104 & 105 & 106 & 107 & 108 & 109 & 110 & 111 \\
\hline 20 Apparel and accessories & 112 & 113 & 114 & & & & & \\
\hline 21 Lumber and wood products & 115 & 116 & 117 & 118 & 119 & & & \\
\hline 22 Furniture & 120 & 121 & & & & & & \\
\hline 23 Pulp, paper, paper products & 122 & 123 & 124 & 125 & 126 & 127 & 128 & \\
\hline 24 Publishing and printing & 129 & 130 & 131 & & & & & \\
\hline 25 Leather and leather products & 191 & 192 & 193 & & & & & \\
\hline 26 Rubber products & 187 & 188 & 189 & 190 & & & & \\
\hline \multirow[t]{4}{*}{27 Basic chemicals } & 132 & 133 & 134 & 135 & 136 & 137 & 138 & 139 \\
\hline & 142 & 143 & 144 & 145 & 146 & 147 & 148 & 149 \\
\hline & 152 & 153 & 154 & 155 & 156 & 157 & 158 & 159 \\
\hline & 162 & 163 & & & & & & \\
\hline 28 Chemical fibers & 164 & 165 & & & & & & \\
\hline 29 Other chemicals & 166 & 167 & 168 & 169 & 170 & 171 & 172 & 173 \\
\hline 30 Petroleum products & 174 & 175 & 176 & 177 & 178 & 179 & 180 & 181 \\
\hline 31 Coal products & 183 & 184 & 185 & & & & & \\
\hline \multirow[t]{2}{*}{32 Stone, clay \& glass products } & 194 & 195 & 196 & 197 & 198 & 199 & 200 & 201 \\
\hline & 204 & 205 & 206 & & & & & \\
\hline 33 Steel manufacturing & 207 & 208 & 209 & 210 & & & & \\
\hline \multirow[t]{2}{*}{34 Other steel } & 211 & 212 & 213 & 214 & 215 & 216 & 217 & 218 \\
\hline & 221 & 222 & & & & & & \\
\hline \multirow[t]{2}{*}{35 Non-ferrous metals } & 223 & 224 & 225 & 226 & 227 & 228 & 229 & 230 \\
\hline & 233 & & & & & & & \\
\hline 36 Metal products & 234 & 235 & 236 & & & & & \\
\hline \multirow[t]{3}{*}{37 General machinery equipment } & 237 & 238 & 239 & 240 & 241 & 242 & 243 & 244 \\
\hline & 247 & 248 & 249 & 250 & 251 & 252 & 253 & 254 \\
\hline & 257 & 258 & 259 & 278 & 281 & & & \\
\hline 38 Electrical machinery & 269 & 270 & 271 & & & & & \\
\hline 39 Equipment and supplies for household use & 260 & 261 & 262 & & & & & \\
\hline 40 Other electrical machinery & 263 & 264 & 265 & 266 & 267 & 268 & 272 & 273 \\
\hline 41 Motor vehicles & 275 & 276 & & & & & & \\
\hline 42 Ships & 279 & 280 & 282 & & & & & \\
\hline 43 Other transportation equipment & 277 & 283 & 284 & 285 & 286 & 287 & 288 & 289 \\
\hline 44 Precision machinery \& equipment & 290 & 291 & 292 & 293 & 294 & 295 & & \\
\hline 45 Other manufacturing & 186 & 296 & 297 & 298 & 299 & 300 & 301 & 302 \\
\hline
\end{tabular}

